\title{
Assessment the Quality of Bottled Drinking Water Through Mamdani Fuzzy Water Quality Index
}

\section{Ghorban Asgari}

Hamadan University of Medical Sciences School of Public Health

\section{Ensieh Komijani}

Hamadan University of Medical Sciences School of Public Health

Abdolmotaleb Seid-Mohammadi

Hamadan University of Medical Sciences School of Public Health

Mohammad Khazaei ( $\nabla$ khazaei57@gmail.com )

Hamadan University of Medical Sciences School of Public Health https://orcid.org/0000-0002-7810$522 X$

\section{Research Article}

Keywords: Fuzzy inference system, Water quality index, Bottled water, Defuzzification, Membership functions

Posted Date: June 4th, 2021

DOl: https://doi.org/10.21203/rs.3.rs-453927/v1

License: (c) (i) This work is licensed under a Creative Commons Attribution 4.0 International License. Read Full License

Version of Record: A version of this preprint was published at Water Resources Management on October 29th, 2021. See the published version at https://doi.org/10.1007/s11269-021-03013-z. 


\title{
Assessment the quality of bottled drinking water through Mamdani Fuzzy water quality
} index

Ghorban Asgari ${ }^{\mathrm{a}, \mathrm{b}}$, Ensieh Komijani ${ }^{\mathrm{a}}$, Abdolmotaleb Seid-Mohammadi ${ }^{\mathrm{b}}$, Mohammad Khazaei $^{\mathrm{a}^{*}}$,

a. Department of Environmental Health Engineering, Research Center for Health Sciences, Hamadan University of Medical Sciences, Hamadan, Iran

b. Social Determinants of Health Research Center (SDHRC), Environmental Health Engineering, School of Public Health, Hamadan University of Medical Sciences, Hamadan, Iran;

*Corresponding Author:

Email: Mohammad Khazaei: khazaei57@gmail.com,

Address: Hamadan University of Medical Sciences, Hamadan, Iran. P.O. Box: 6517838736.

\begin{abstract}
In this investigation, an innovative index was developed based on the fuzzy inference system for assessing the quality of bottled drinking waters. A method was developed to aggregate the values obtained from the defuzzification step. A total number of 24 quality parameters revealing the characteristics of bottled were in terms of physiochemical, dietary, toxic, and pathogenic aspects were selected as the input parameters. 30 samples were taken from the independent brands found in the Hamadan province retail market to evaluate the bottled water quality index (BWQI). Results show that the values obtained from measuring the parameters are in the range of the standard levels set by national regulations. The BWQI scores obtained from samples were in the range of 61.2-73.8 attributing to the marginal and fair descriptive
\end{abstract}


classes. Sensitivity analysis using the Monte Carlo algorithm reveals that the parameters $\mathrm{NO}_{3}$, $\mathrm{Na}$, hardness, and $\mathrm{NO}_{2}$ have the most impact on the BWQI scores.

Keywords: Fuzzy inference system, Water quality index, Bottled water, Defuzzification, Membership functions.

\section{Introduction}

The worldwide increasingly consumption of bottled waters during current years is mainly due to the reasons such as low-price, availability, supposed better quality than piped water, consumer higher social status indication (mainly in high price brands), and the prevalent idea that the bottled waters contain fewer contaminants (Felipe-Sotelo, Henshall-Bell et al. 2015; Ahmed, Rashid et al. 2016). Accordingly, the global bottled water market is viewed as the quickest expanding section of the non-alcoholic beverage sector (Rahman, Barua et al. 2017).

However, despite the increasing rate of bottled water consumption, the lack of comprehensive frameworks to set a quality index for the bottled waters can be observed (Espejo-Herrera, Kogevinas et al. 2013). Water quality indices (WQIs) are now widely used to support decisionmakers in terms of water quality management (Hounslow 2018). WQIs comprise different water quality parameters into one output indicator representing the easily and quickly recognized scores (UNEP 2007; Council 2012).

As denoted above, most WQIs have served as tools to monitor the quality of surface water, groundwater, and piped drinking water sources. Only a few studies are taking into account appropriate technical approaches to introduce a quality index for bottled waters (Toma, Ahmed et al. 2013; Tsakiris, Alexakis et al. 2017). The prominent studies among the former attempts to develop a water quality index are the works of Horton (Horton 1965) and Walski (Walski and Parker 1974). They developed indices to evaluate surface water sources, mainly rivers, 
using the input parameters temperature, nutrients, suspended solids, turbidity, coliform bacteria, dissolved oxygen, color, $\mathrm{pH}$, grease, odor, and toxic. The Walski's index was based on a geometric mean of transformed values regarding the input parameters through a range of zero to one (Uusitalo, Lehikoinen et al. 2015). The most common WQI was developed by the National Sanitation Foundation (NSF) (Ott 1978). Afterward, numerous modified water quality indices have been developed according to the NSF approach (Mukhopadhay, Majumder et al. 2009; Khazaei, Mahvil et al. 2013; Fard, Mahvi et al. 2014; Nabizadeh, Mahvi et al. 2018).

However, some problems arise when these traditional indices are used. The main problem is reflecting the same effects on the output index score from the input values having different distances from a borderline (Icaga 2007). Consequently, in terms of making decisions about boundary values, the uncertain distinction between each mode of the index can occur that involved a vagueness nature in the output index (Chang, Chen et al. 2001). Furthermore, the uncertainty characteristics of environmental issues cannot be considered in the traditional WQIs (Gharibi, Mahvi et al. 2012).

The computational methods according to the artificial intelligence (AI) have been applied increasingly in the environmental issues during the recent decade, mainly because of the tremendous development in the computational techniques and the availability of powerful software tools (Gharibi, Sowlat et al. 2012). Fuzzy logic is one of the most effective tools of AI that was first introduced by Zadeh (1965)(Zadeh 1965). Indices developed based on fuzzy logic are believed to have the ability to indicate the human thoughts and processing the qualitative uncertain values expressed through the linguistic terms (Yekta, Khazaei et al. 2015; Nabizadeh, Mahvi et al. 2018).

In this work, we aim to introduce an innovative index for assessing bottled water quality. The fuzzy inference system based on the Mamdani model is served a mathematical framework to 
develop the index. During the study period, all bottled water brands found in the Hamadan province markets were sampled and analyzed to determine the water quality parameters and test the introduced indices.

\section{Materials and methods}

\section{Study Area}

Hamadan province is located in the western part of Iran, having a population of over 1.7 million (Gitau, Chen et al. 2016) and an area of $20200 \mathrm{~km}^{2}$ (Fig.1). Over $96.64 \%$ of drinking water consumption is provided using a public water distribution system (Abtahi, Yaghmaeian et al. 2016). Besides the piped drinking water, the population is also served by the bottled water distribution system. Based on the information obtained from the national bottled water association (NBWA), there are 110 active bottled water production companies in Iran (IBWA 2018/07/08). Among them, 30 different bottled water brands were distributed in the Hamadan province market during the study period from September 2018 through March 2019. As represented in Table 1, 3 brands are produced in the province and 27 others are imported from the other provinces. Furthermore, 12 brands from mineral and the remaining 18 brands are drinking grade. According to the privacy considerations, the name of brands was not mentioned in the results, instead, the samples were denoted by numbers. Fig. 1 also shows the approximate locations of the bottled water manufactures all around the country. 


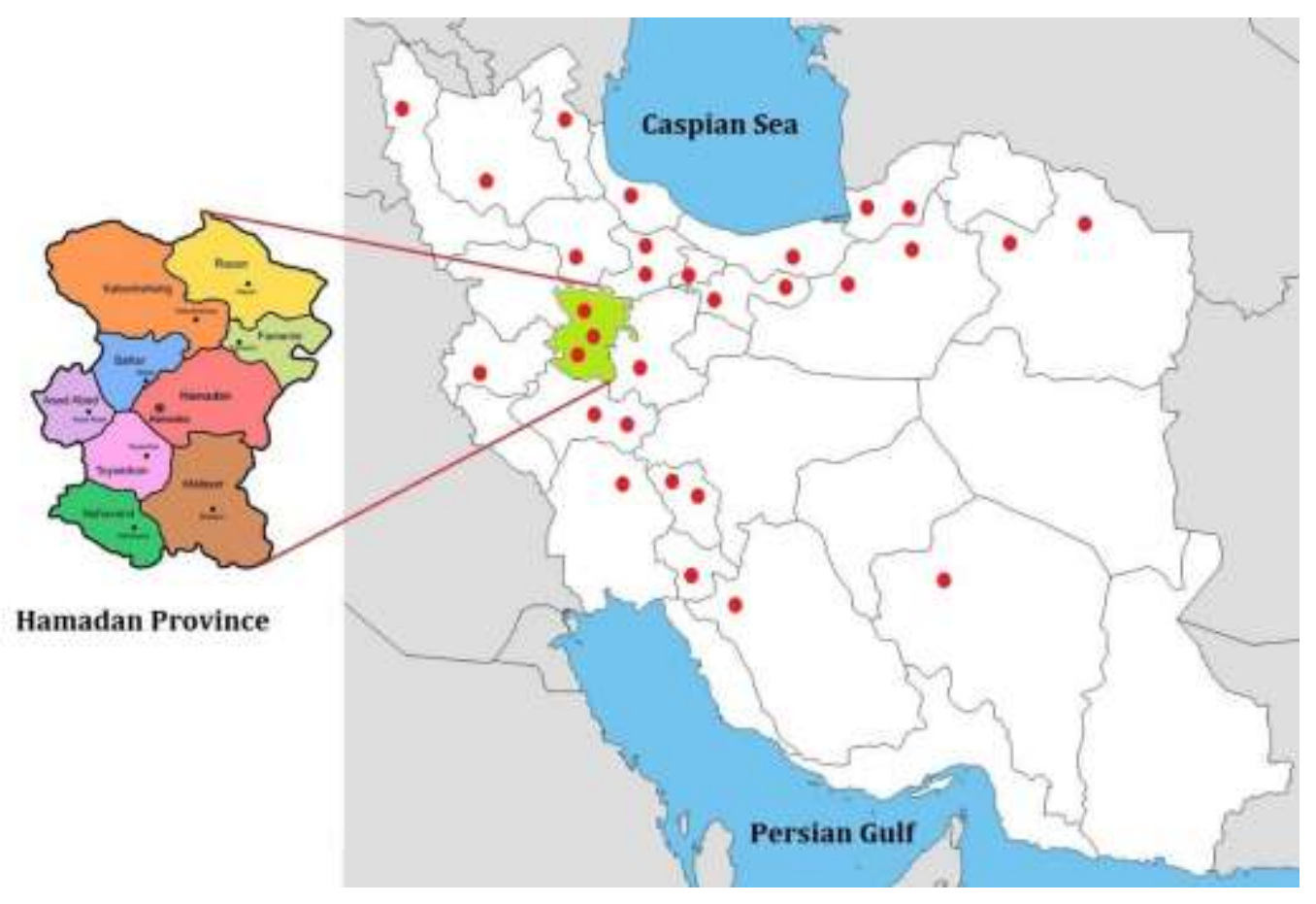

Figure 1. Map of the study area and the manufactures locations of bottled water samples (Mosaferi, Hajizadeh et al. 2007; Abtahi, Yaghmaeian et al. 2016)

Table 1. List of water brands studied in this work.

\begin{tabular}{|c|c|c|}
\hline $\begin{array}{l}\text { Brand } \\
\text { Name }\end{array}$ & $\begin{array}{l}\text { Address } \\
\text { (Province) }\end{array}$ & Type \\
\hline Armos & West Azarbaijan & Drinking \\
\hline Alvand & Hamedanh & Drinking \\
\hline Wistler & Markazi & Drinking \\
\hline Vivante & Kohgiluyeh & Mineral \\
\hline Vata & Ardabil & Mineral \\
\hline Vanitar & Kerman & Drinking \\
\hline Avrin & East Azarbaijan & Drinking \\
\hline Damavand & Tehran & Drinking \\
\hline ijab & Kermanshah & Mineral \\
\hline Hoolasoo & Ghazvin & Drinking \\
\hline Parsi & Tehran & Drinking \\
\hline $\begin{array}{l}\text { Negin } \\
\text { kohsar }\end{array}$ & Qazvin & Drinking \\
\hline Crest & Gilan & Mineral \\
\hline Di di & Ardabil & Mineral \\
\hline Versay & Mazandaran & Drinking \\
\hline Iceland & Lorestan & Mineral \\
\hline Axaya & Hamedan & Mineral \\
\hline Aftab & Hamedan & Mineral \\
\hline $\begin{array}{l}\text { Cheshme } \\
\text { bolbol }\end{array}$ & Golestan & Mineral \\
\hline
\end{tabular}




\begin{tabular}{lll} 
Oxsina & Golestan & Drinking \\
Binalood & Khorasan Razavi & Drinking \\
Iranoosh & Khorasan Razavi & Mineral \\
Bolursa & Semnan & Mineral \\
Mishvan & Zanjan & Drinking \\
iran & Semnan & Drinking \\
Hableh rod & Qazvin & Drinking \\
Bika & Alborz & Drinking \\
Souver & Lorestan & Mineral \\
Bisheh & Fars & Mineral \\
Aqoalife & Tehran & Drinking \\
Dasani & & \\
\hline
\end{tabular}

\section{Parameters measuring and instrumentation}

Samples were collected from retails of Hamadan province. Two $0.5 \mathrm{~L}$ bottles were purchased per each brand. Samples then were transferred to the laboratory and the values of nitrate, $\mathrm{pH}$, fluoride, hardness, calcium, magnesium, sodium, chloride, sulfate, nitrite, turbidity, coliforms, and toxic metals were measured according to the Standard Methods. Metals, including iron, manganese, lead, mercury, cadmium, arsenic, barium, potassium zinc, and cobalt were measured using a Spectro Arcos ICP-optical emission spectrometer (SPECTRO Analytical Instruments, Kleve, Germany) based on radial plasma observation(Shakerkhatibi, Mosaferi et al. 2019). The values of $\mathrm{pH}$, turbidity, and the concentration of anions were determined according to their instruction mentioned in the Standard Methods (American Public Health Association 1995). Total and fecal coliforms were determined using multiple tube technique based on approaches developed by Standard Methods (American Public Health Association 1995).

\section{Determining Bottled water indices}

Water quality indices usually have five components consist of 1) Input parameters, 2) Weights of parameters, 3) A normalization method, 4) A framework to determine the index, and 5) A protocol for the index judgment. 
Here, a brief approach to develop a bottled water quality index is presented.

\section{Bottled water quality index (BWQI)}

Based on the following steps, in this work, the bottled water quality index (BWQI) is introduced:

1) The input parameters were selected regarding their human health risk, dietary, and aesthetical considerations (Khazaei, Mahvil et al. 2013; Fard, Mahvi et al. 2014; Abtahi, Yaghmaeian et al. 2016). Therefore, parameters were classified into five categories as represented in Table 2. Accordingly, the minerals such as calcium, magnesium, and fluoride were added in the input parameters in terms of their dietary values recommended by national and international agencies (Organization 2005; Katz, Njike et al. 2009; Abtahi, Yaghmaeian et al. 2016; Selvaraj, Mubarakali et al. 2016; Khazaei, Rahmani et al. 2019). Physicochemical properties, $\mathrm{pH}$, and turbidity are selected because of their role in the treatment processes, mainly in the disinfection process. Mercury, cadmium, lead, chromium, and arsenic were considered as toxic elements according to their carcinogenic and toxic risks (Bahmani and Palangi 2018).

Table 2. Parameters considered in the BWQI

\begin{tabular}{|c|c|c|c|}
\hline Category & Parameter & Reason & Reference \\
\hline Toxic Metal & $\begin{array}{l}\text { Mercury, lead, arsenic, cadmium, } \\
\text { chromium, }\end{array}$ & $\begin{array}{l}\text { Carcinogenic and } \\
\text { toxic risk }\end{array}$ & $\begin{array}{l}\text { (Haraoui, Tao } \\
\text { et al. 2014; } \\
\text { Bahmani and } \\
\text { Palangi 2018) }\end{array}$ \\
\hline $\begin{array}{l}\text { Physico- } \\
\text { chemical } \\
\text { Properties }\end{array}$ & $\mathrm{pH}$, Turbidity & $\begin{array}{l}\text { Aesthetical, } \\
\text { Preparing biological } \\
\text { growth }\end{array}$ & $\begin{array}{l}\text { (Tsakiris, } \\
\text { Alexakis et al. } \\
\text { 2017; Eslami, } \\
\text { Yaghmaeian et } \\
\text { al. 2019) }\end{array}$ \\
\hline $\begin{array}{l}\text { Dietary } \\
\text { Elements }\end{array}$ & $\begin{array}{l}\text { Calcium, Fluoride magnesium, } \\
\text { cobalt, potassium, sodium }\end{array}$ & $\begin{array}{l}\text { Nutritional } \\
\text { Importance }\end{array}$ & $\begin{array}{l}\text { (Mohebbi, } \\
\text { Saeedi et al. } \\
\text { 2013; Abtahi, } \\
\text { Yaghmaeian et } \\
\text { al. 2016; } \\
\text { Khazaei, }\end{array}$ \\
\hline
\end{tabular}


Rahmani et al.

2019)

(Council 1989;

Gastric disorders,

Espejo-

Anions

Nitrate, Nitrite, chloride, sulfate,

probable

carcinogenic

Herrera,

Kogevinas et al. 2013)

(Alimentarius

Microbial

Quality

Total coliforms, Fecal coliforms

Pathogenic

2001;

contaminants Hounslow

2018)

2) A team comprising 10 multi-disciplinary decision-makers (DMs) determined the weights of parameters based on AHP weighting techniques. Then, weights obtained from the decision-makers were aggregated as follows

$$
\left\{\begin{array}{l}
W_{p}=\sum_{l=1}^{Z} V_{l} W_{p l} \\
\sum_{p=1}^{P} W_{p}=1
\end{array}\right.
$$

Where $W_{p}$ is the aggregated weight assigned to $p$ th parameter, $V_{l}$ represents weight determined for the $l$ th decision-maker, and $W_{p l}$ is the weigh proposed by $l$ th DM for $p$ th parameter. Table 3 presents the acquired weights assigned to each parameter.

3) Parameters have their scales for the report of their values such as $\mathrm{mg} / \mathrm{L}, \mathrm{NTU}$, and MPN/100 $\mathrm{mL}$ so that the difference in the scale (or units) hinders them to be integrated and form a unique value. Accordingly, to develop an index representing all various input parameters, the values of parameters should primarily be developed into the unit free values. This process involves a mathematical basis and known as the normalization. The result of normalization is unit-less values obtained from the source values laid between 0 and 1 . In this work, the fuzzy membership functions were applied to normalize the input values through the fuzzification process which receives the input 
variables considering the linguistic terms as represents in Table 3. Accordingly, Table 3 represents the categories of parameters according to those that have a desirable range and those without a desirable range. Furthermore, the linguistic terms, the fuzzy sets, and the original form of the parameters can be found in Table 3. Fig. 2 shows triangular $\left(\mathrm{FS}=\left(a_{1}, a_{2}, a_{3}\right)\right)$ and trapezoidal $\left(\mathrm{FS}=\left(a_{1}, a_{2}, a_{3}, a_{4}\right)\right)$ fuzzy sets $(\mathrm{FS})$ used for the normalization process.
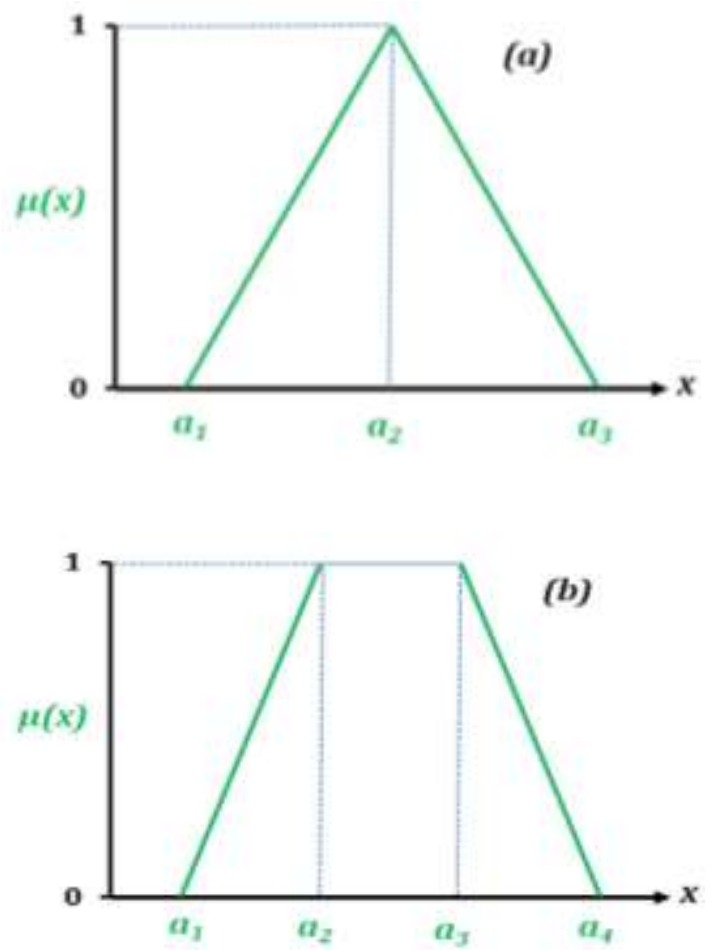

Figure 2.Triangular (a) and trapezoidal (b) fuzzy sets 
Table 3. Description of the input variables according to nature (desirable, undesirable) and the assigned fuzzy sets.

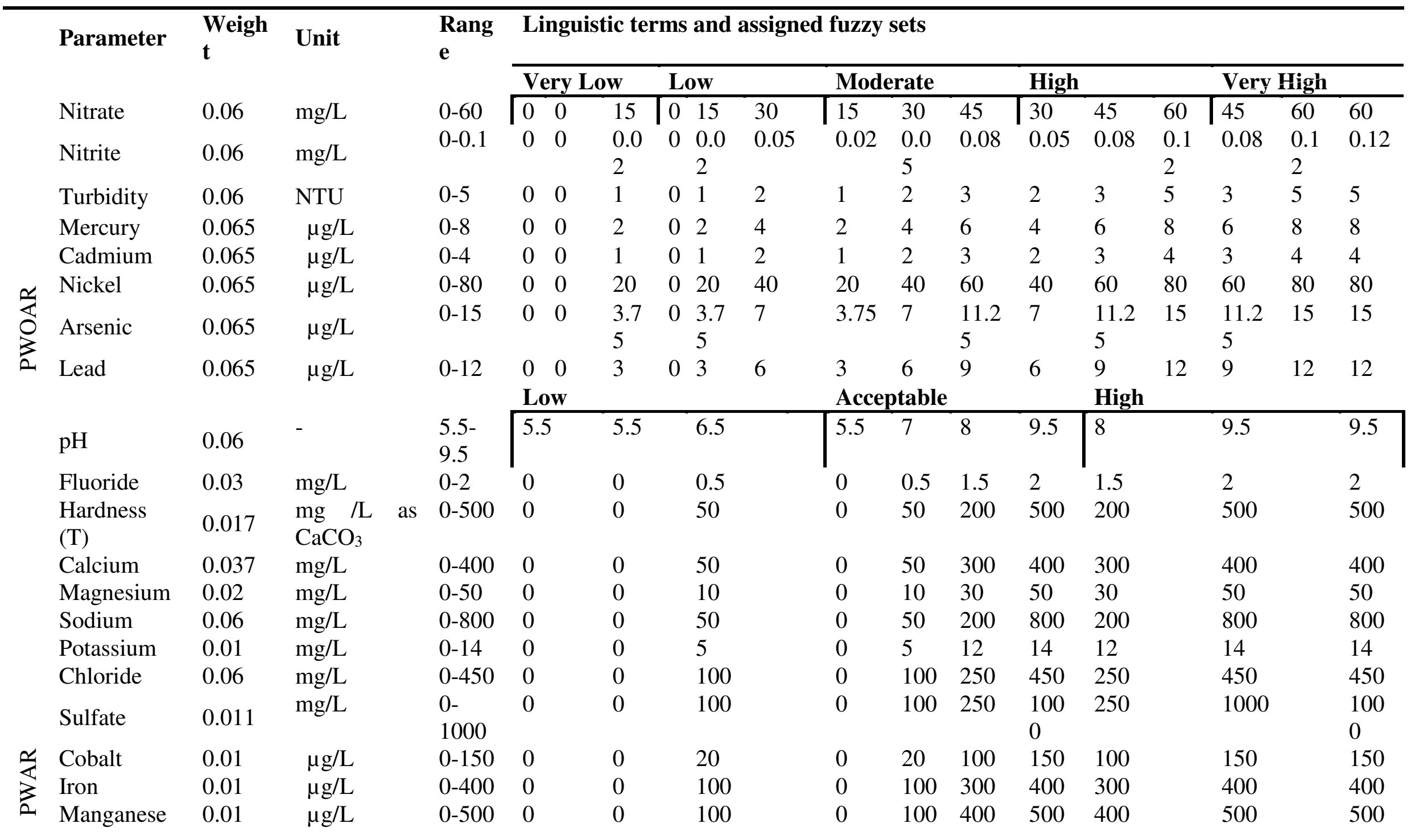




\begin{tabular}{|c|c|c|c|c|c|c|c|c|c|c|c|c|c|c|}
\hline & Zinc & 0.01 & $\mathrm{mg} / \mathrm{L}$ & $0-4$ & 0 & 0 & 1 & 0 & 1 & 3 & 4 & 3 & 4 & 4 \\
\hline & Copper & 0.01 & $\mathrm{mg} / \mathrm{L}$ & $0-2.5$ & 0 & 0 & 0.5 & 0 & 0.5 & 1 & 2.5 & 1 & 2.5 & 2.5 \\
\hline & & & & & \multicolumn{5}{|c|}{ Presence } & \multicolumn{5}{|c|}{ Absence } \\
\hline \multirow{2}{*}{$\begin{array}{l}\frac{1}{2} \\
0 \\
0 \\
2\end{array}$} & $\begin{array}{l}\text { Total } \\
\text { Coliform }\end{array}$ & 0.1 & $\begin{array}{l}\text { MPN/100m } \\
\mathrm{L}\end{array}$ & $0-1$ & 0 & 0 & 1 & & & 0 & & 1 & 1 & \\
\hline & $\begin{array}{l}\text { Fecal } \\
\text { Coliform }\end{array}$ & 0.1 & $\begin{array}{l}\text { MPN/100m } \\
\text { L }\end{array}$ & $0-1$ & 0 & 0 & 1 & & & 0 & & 1 & 1 & \\
\hline
\end{tabular}




$$
\mu(x)= \begin{cases}\frac{\left(x-a_{1}\right)}{\left(a_{2}-a_{1}\right)}, & a_{1} \leq x \leq a_{2} \\ \frac{\left(x-a_{3}\right)}{\left(a_{2}-a_{3}\right)}, & a_{2} \leq x \leq a_{3} \\ 0, & \text { Otherwise. }\end{cases}
$$

$$
\mu(x)= \begin{cases}\frac{\left(x-a_{1}\right)}{\left(a_{2}-a_{1}\right)}, & a_{1} \leq x \leq a_{2} \\ 1, & a_{2} \leq x \leq a_{3} \\ \frac{\left(x-a_{4}\right)}{\left(a_{3}-a_{4}\right)}, & a_{3} \leq x \leq a_{4} \\ 0, & \text { Otherwise }\end{cases}
$$

where $x$ is an input value of parameter $\mathrm{j}, \mu(x)$ is a membership function of $x$, and $a_{1}$ through $a_{4}$ values are the components of the triangular or trapezoidal fuzzy set (FS). Fig. 3(a) reveals how the fuzzification process works. As shown, each input value, $x_{\mathrm{p}}$ produces two membership functions $\mu\left(x_{p, i}\right)$ and $\left(x_{p, j}\right)$, be owned by two adjacent fuzzy sets $F S_{i}$ and $F S_{j}$, laid between 0 and 1.

4) The normalized values $\mu\left(x_{p, i}\right)$ and $\mu\left(x_{p, j}\right)$ are then mirrored on the Y-axis of the coordination system, representing in Fig. 3(b), which were arranged for the defuzzification process. Mapping the values belonged to the input fuzzy sets $F S_{i}$ and $F S_{j}$ on the output fuzzy sets $F S_{i}$ and $F^{\prime} S_{j}$ can be achieved using the fuzzy inference rules. The fuzzy inference rules decide the belongingness of an input FS to a predetermined output $F$ S.

Fuzzy inference rules are the logic if-then instructions enacted by the multi-disciplinary decision-makers (DMs). The set of fuzzy inference rules applied to manage the logic relationships between input and output fuzzy numbers is known as the inference engine 
instance, considering the parameter, turbidity, a logic inference rule is: if the turbidity is very low (VL), then, the turbidity sub-index is very good $(V G)$. Here, the VL and VG are the linguistic terms to describe the input (FS) and output (FS) fuzzy sets, respectively.

Consequently, each input crisp parameter value, $x_{p}$ (e.g. $x_{p}$ can be a measured amount of turbidity as NTU in a bottled water sample) will produce two values $y_{p, i}$ and $y_{p, j}$ belonged to the adjacent fuzzy sets $F S_{i}$ and $F S_{j}$, respectively, as illustrated in Fig. 3. Accordingly, a set of 972 rules were produced and applied based on the Mamdani inference method.
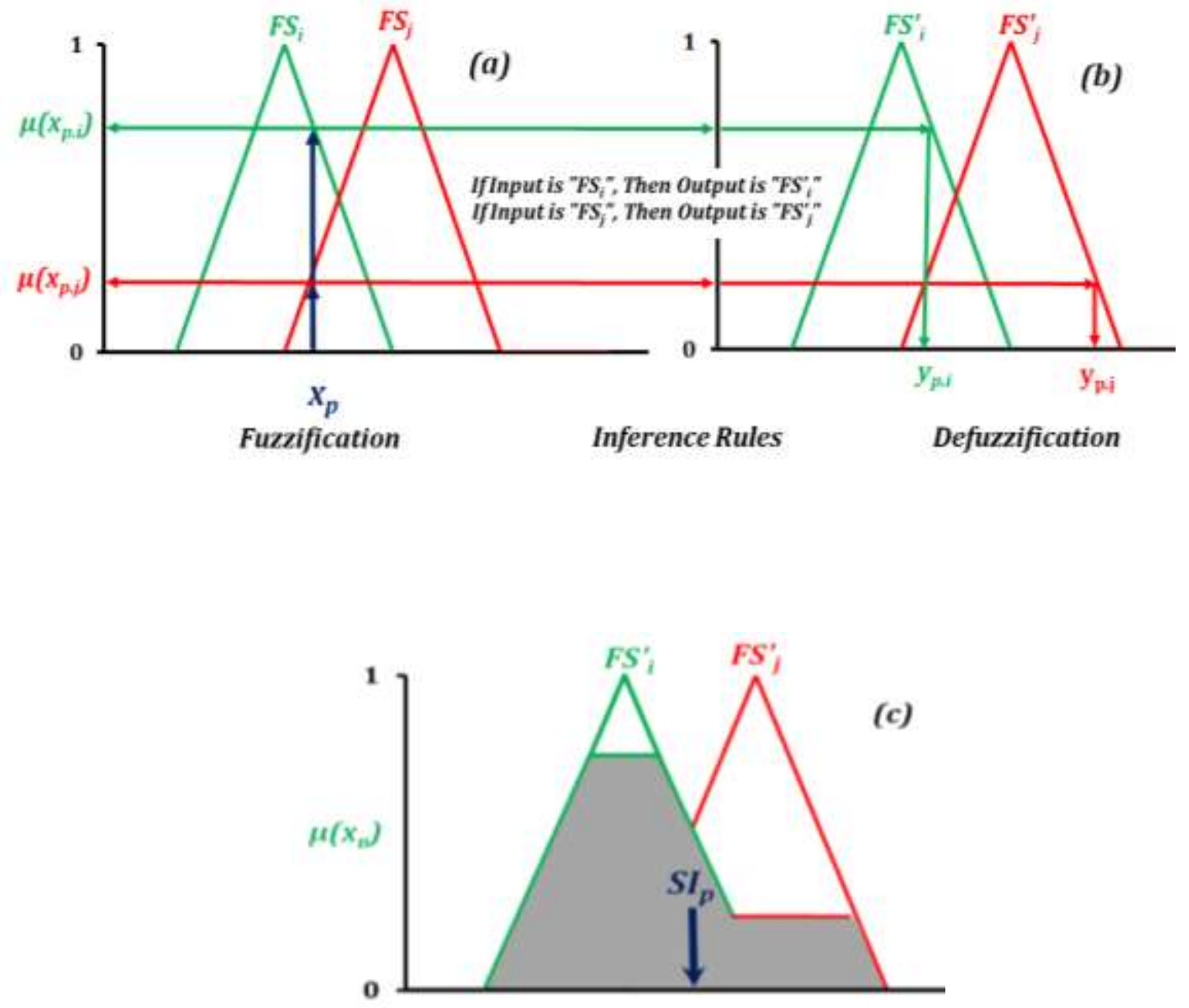
Figure 3. Operation of a single-input-single-output fuzzy inference system (FIS) including the fuzzification (a), using the inference rules (b), and defuzzification by determining the resultant vector, $y_{p, r}(\mathrm{c})$.

The values $y_{p, i}$ or $y_{p, j}$ can be defined as the mapped quantities on the X-axis of the defuzzification coordination system, which is attributed to the input $x_{p}$ after applying the inference rules. For triangular fuzzy sets, $y_{p, i}$ and $y_{p, j}$ can be obtained using the Eqs. 4 and 5, respectively. Furthermore, $y_{p, i}$ and $y_{p, j}$ can be determined by applying Eqs. 6 and 7 , respectively in the case of trapezoidal fuzzy sets.

$$
\begin{aligned}
& \left\{\begin{array}{l}
y_{p, i}=\mu\left(x_{p, i}\right) \times\left(a_{1, i}-a_{3, i}\right)+a_{3, i} \quad \text { (4) } \\
y_{p, j}=\mu\left(x_{p, j}\right) \times\left(a_{1, j}-a_{3, j}\right)+a_{3, j}
\end{array} \text { (5) } \quad\right. \text { for the triangular fuzzy sets } \\
& \left\{\begin{array}{l}
y_{p, i}=\mu\left(x_{p, i}\right) \times\left(a_{3, i}-a_{4, i}\right)+a_{4, i} \quad \text { (6) } \\
y_{p, j}=\mu\left(x_{p, j}\right) \times\left(a_{3, j}-a_{4, j}\right)+a_{4, j} \quad \text { (7) }
\end{array},\right. \text { for the trapezoidal fuzzy sets }
\end{aligned}
$$

where the $a_{1, i}$ through $a_{4, i}$ and the $a_{1, j}$ through $a_{4, j}$ are the values of triangular or trapezoidal fuzzy sets, $F S_{i}$ and $F S_{j}$, respectively. $\mu\left(x_{p, i}\right)$ and $\mu\left(x_{p, j}\right)$, as mentioned in step (3), are the membership functions produced from the input parameter value, $x p$. To obtain the parameter sub-index, $S I_{p}$, at first, the $y_{p, i}$ and $y_{p, j}$ should be integrated to form the resultant value, $y_{p, r}$. The resultant value, $y_{p, r}$ can be obtained using several approaches known as defuzzification methods (Silvert 2000; Ross 2004; OcampoDuque, Osorio et al. 2013). Here, we obtain a new approach to find $y_{p, r}$ from values $\mathrm{y}_{\mathrm{p}, \mathrm{i}}$ and $\mathrm{y}_{\mathrm{p}, \mathrm{j}}$ by using Eq. 8 .

$$
y_{p, r}= \begin{cases}\left(\frac{\mu\left(x_{p, i}\right) \times y_{p, i}+\mu\left(x_{p, j}\right) \times y_{p, j}}{\sum_{(i+j)} \mu\left(x_{p}\right)}\right), & \sum_{(i+j)} \mu\left(x_{p}\right) \neq 0 \\ 0, & \sum_{(i+j)} \mu\left(x_{p}\right)=0\end{cases}
$$

As observed, the magnitudes of $y_{p, i}$ and $y_{p, j}$ are adjusted by the amounts of $\mu\left(x_{p, i}\right)$ and $\mu\left(x_{p, j}\right)$, respectively. 
Then, regarding the nature of each parameter, the $S I_{p}^{q}$ (sub-index of the parameter, $p$ in BWQI) can be obtained as follows.

1. For the parameters comprise undesirable amounts at all levels, so that the zero value is the best (toxic metals, turbidity, nitrate, nitrite, coliforms), the $S I_{p}^{q}$ is determined using Eq. 9.

$$
S I_{p}^{q}=\left(100-y_{p, r}\right)
$$

2. For those have the desired values in a range of levels in such a way that lower than and above the range be considered as unacceptable values $(\mathrm{pH}$, Fluoride, Calcium, Magnesium, Iron, Manganese, Zinc, Cobalt, Copper, and Hardness) the $S I_{p}$ is determined by applying Eq. 10 .

$$
S I_{p}^{q}=y_{p, r}
$$

The bottled water quality index (BWQI) can be determined using Eq. 11.

$$
B W Q I=\frac{\sum_{1}^{P}\left(W_{p} \times S I_{p}^{q}\right)}{\sum_{1}^{P} W_{p}}, \quad p \in\{1,2, \ldots P\}
$$

5) To introduce a facile and precise judgment on the water quality of bottled water samples, a straightforward protocol was designed according to the literature (UNEP 2007; DOE 2010; Mohebbi, Montazeri et al. 2013) and comprises the descriptive terms and color chart as shown in Table 4.

Table 4. The judgment protocol used for BWQI and BWLI

\begin{tabular}{|l|l|l|l|}
\hline \multicolumn{2}{|l|}{ Range } & Description & Color \\
\hline 0 & 44 & Poor & \\
\hline 45 & 64 & Marginal & \\
\hline 65 & 79 & Fair & \\
\hline 80 & 94 & Good & \\
\hline 95 & 100 & Excellent & \\
\hline
\end{tabular}

\section{Sensitivity analysis}

Sensitivity analysis aims to determine the influence of each input parameter, $p$ on the BWQI score. To obtain the sensitivity level of the index regarding the input values, each parameter 
was withdrawn separately from the BWQI and the consequently reduced indices were compared with the original form. Uncertainty and sensitivity analyses were conducted using Crystal Ball, an Excel add-in by Oracle. Furthermore, triangle distributions were used for all uncertain inputs.

\section{Results and discussion}

Table 5 presents the results of laboratory analyses for samples took from 30 separated brands found in the Hamadan province retail market. As represented in Table 5, the mean values of 24 input parameters are in the safe range of the national standard of bottled water quality (Chang, Chen et al. 2001) and Codex bottled water quality suggestions(Alimentarius 2001; Alimentarius 2008). Consequently, low scores of BWQI were not being expected. Samadi et al. examined 17 bottled water samples gathered in the Hamadan retail market during the years 2006 and 2007. The values inscribed on the bottle labels were compared with the parameter values determined in the laboratory experiments (Samadi, Rahmani et al. 2009). The average values obtained for the input parameters in our study had good confidence with those reported by Samadi et al(Samadi, Rahmani et al. 2009). Fig. 4 exhibits the scattering pattern of cations and anions measured in 30 obtained samples through a Piper plot. As shown, the bottled water brands entered into the sample set mainly belong to the magnesium bicarbonate type (Hounslow 2018). As shown, low contents of $\mathrm{Cl}$ and $\mathrm{SO}_{4}$ ions are observed, instead, the main share of the anions comprising $\mathrm{HCO}_{3} \cdot$ Most studies conducted in the western part of Iran reported bicarbonate type for bottled water and groundwater sources (Bahmani and Palangi 2018; Soleimani, Nasri et al. 2018; Shakerkhatibi, Mosaferi et al. 2019). Fig. 4 also reveals that most of mineral bottled water samples belong to the calcium type water category confirming the groundwater sources withdrawn from aquifers constructed from carbonate sedimentary rocks (Dinelli, Lima et al. 2010; Hounslow 2018). 
100 Table 6 shows the sub-indices, $S I_{p}^{q}$ which are calculated for parameter $p$ attributing to the brand $101 q$. Regarding the weights assigned to each parameter and the fuzzy inference rules, BWQI 102 scores were obtained for each brand, as illustrated in Fig. 5. From Fig. 5, it is also revealed that 103 the BWQI scores are laid between 45 and 79, which is indicated as "marginal" and "fair" quality 104 (red and yellow region, respectively) according to the judgment protocol shown in Table 4. 105 
Table. 5. The values of input parameters measured in bottled water samples

\begin{tabular}{|c|c|c|c|c|c|c|c|c|c|c|c|c|c|c|c|}
\hline \multirow{2}{*}{ Parameter } & \multicolumn{15}{|c|}{ Sample No. } \\
\hline & 1 & 2 & 3 & 4 & 5 & 6 & 7 & 8 & 9 & 10 & 11 & 12 & 13 & 14 & 15 \\
\hline $\mathrm{NO}_{3}(\mathrm{mg} / \mathrm{L})$ & 3.8 & 13.9 & 27.4 & 8.2 & 4.8 & 22.4 & 16.0 & 3.9 & 4.6 & 1.0 & 16.7 & 2.0 & 4.7 & 2.9 & 1.2 \\
\hline $\mathrm{NO}_{2}(\mathrm{mg} / \mathrm{L})$ & 0.0 & 0.1 & 0.1 & 0.0 & 0.0 & 0.0 & 0.0 & 0.0 & 0.0 & 0.0 & 0.0 & 0.0 & 0.0 & 0.0 & 0.0 \\
\hline pH & 7.2 & 7.3 & 7.5 & 7.2 & 7.5 & 7.3 & 7.8 & 7.6 & 6.8 & 6.6 & 6.9 & 7.5 & 6.8 & 6.6 & 7.0 \\
\hline $\mathbf{F}(\mathrm{mg} / \mathrm{L})$ & 0.1 & 0.1 & 0.4 & 0.3 & 0.8 & 0.2 & 0.3 & 0.5 & 0.3 & 0.1 & 0.7 & 0.3 & 0.2 & 0.4 & 0.2 \\
\hline $\begin{array}{l}\text { Hardness } \\
\left(\mathrm{mgCaCO}_{3} / \mathrm{L}\right)\end{array}$ & 112.7 & 119.5 & 98.9 & 147.1 & 104.1 & 238.9 & 102.2 & 116.9 & 131.8 & 36.1 & 141.9 & 47.9 & 104.9 & 178.1 & 90.9 \\
\hline $\mathrm{Ca}(\mathrm{mg} / \mathrm{L})$ & 24.5 & 30.7 & 24.8 & 29.0 & 28.3 & 31.6 & 7.6 & 18.9 & 23.1 & 7.1 & 17.5 & 5.9 & 23.1 & 24.6 & 0.6 \\
\hline $\operatorname{Mg}(\mathrm{mg} / \mathrm{L})$ & 12.5 & 10.4 & 9.0 & 18.1 & 8.1 & 38.9 & 20.2 & 16.9 & 17.9 & 4.4 & 23.8 & 8.0 & 11.5 & 28.3 & 21.7 \\
\hline $\mathrm{Na}(\mathrm{mg} / \mathrm{L})$ & 27.6 & 4.1 & 32.0 & 8.7 & 7.6 & 31.2 & 67.2 & 3.6 & 2.5 & 38.7 & 61.1 & 13.5 & 27.8 & 3.0 & 2.3 \\
\hline $\mathrm{Cl}(\mathrm{mg} / \mathrm{L})$ & 42.0 & 13.0 & 10.0 & 11.0 & 10.0 & 50.0 & 52.0 & 9.0 & 19.0 & 65.0 & 27.0 & 17.0 & 56.0 & 17.0 & 18.0 \\
\hline $\mathrm{SO}_{4}(\mathrm{mg} / \mathrm{L})$ & 11.0 & 29.0 & 22.0 & 23.0 & 3.0 & 78.0 & 67.0 & 26.0 & 10.0 & 22.5 & 29.3 & 13.4 & 9.5 & 19.6 & 40.2 \\
\hline$K(\mathrm{mg} / \mathrm{L})$ & 0.2 & 0.4 & 0.3 & 0.2 & 0.1 & 0.4 & 0.3 & 0.2 & 0.1 & 0.2 & 0.4 & 0.1 & 0.2 & 0.2 & 0.7 \\
\hline Turbidity (NTU) & 0.0 & 0.1 & 0.1 & 0.0 & 0.0 & 0.1 & 0.0 & 0.1 & 0.1 & 0.1 & 0.2 & 0.4 & 0.1 & 0.1 & 0.1 \\
\hline TC (MPN/100mL) & 0.0 & 0.0 & 0.0 & 0.0 & 0.0 & 0.0 & 0.0 & 0.0 & 0.0 & 0.0 & 0.0 & 0.0 & 0.0 & 0.0 & 0.0 \\
\hline FC (MPN/100mL) & 0.0 & 0.0 & 0.0 & 0.0 & 0.0 & 0.0 & 0.0 & 0.0 & 0.0 & 0.0 & 0.0 & 0.0 & 0.0 & 0.0 & 0.0 \\
\hline $\mathrm{Pb}(\mu \mathrm{g} / \mathrm{L})$ & 2.2 & 2.2 & 2.2 & 2.2 & 2.2 & 2.2 & 2.2 & 2.2 & 2.2 & 2.2 & 2.2 & 2.2 & 2.2 & 2.2 & 2.2 \\
\hline Hg $(\mu \mathrm{g} / \mathrm{L})$ & 0.4 & 0.4 & 0.4 & 0.4 & 0.4 & 0.4 & 0.4 & 0.4 & 0.4 & 0.4 & 0.4 & 0.4 & 0.4 & 0.4 & 0.4 \\
\hline $\mathrm{Cd}(\mu \mathrm{g} / \mathrm{L})$ & 0.1 & 0.1 & 0.1 & 0.1 & 0.1 & 0.1 & 0.1 & 0.1 & 0.1 & 0.1 & 0.1 & 0.1 & 0.1 & 0.1 & 0.1 \\
\hline $\mathrm{Ni}(\mu \mathrm{g} / \mathrm{L})$ & 1.2 & 4.8 & 3.1 & 3.4 & 2.1 & 1.9 & 2.6 & 1.5 & 2.1 & 0.5 & 3.6 & 2.1 & 1.4 & 2.1 & 0.3 \\
\hline $\operatorname{As}(\mu \mathrm{g} / \mathrm{L})$ & 0.2 & 0.2 & 0.2 & 0.2 & 0.2 & 0.2 & 0.2 & 0.2 & 0.2 & 0.2 & 0.2 & 0.2 & 0.2 & 0.2 & 0.2 \\
\hline $\mathrm{CO}(\mathrm{mg} / \mathrm{L})$ & 0.0 & 0.0 & 0.0 & 0.0 & 0.0 & 0.0 & 0.0 & 0.0 & 0.0 & 0.0 & 0.0 & 0.0 & 0.0 & 0.0 & 0.0 \\
\hline $\mathrm{Fe}(\mathrm{mg} / \mathrm{L})$ & 0.2 & 0.2 & 0.2 & 0.5 & 0.2 & 0.2 & 0.2 & 0.2 & 0.2 & 0.8 & 0.6 & 0.7 & 0.2 & 0.2 & 2.3 \\
\hline $\operatorname{Mn}(\mathrm{mg} / \mathrm{L})$ & 0.1 & 0.1 & 0.1 & 0.1 & 0.1 & 0.1 & 0.1 & 0.1 & 0.1 & 0.1 & 0.1 & 0.1 & 0.1 & 0.1 & 0.1 \\
\hline $\mathrm{Zn}(\mathrm{mg} / \mathrm{L})$ & 0.0 & 0.0 & 0.0 & 0.0 & 0.0 & 0.0 & 0.0 & 0.0 & 0.0 & 0.5 & 0.0 & 0.0 & 0.0 & 0.0 & 0.0 \\
\hline $\mathrm{Cu}(\mathrm{mg} / \mathrm{L})$ & 0.0 & 0.0 & 0.0 & 0.0 & 0.0 & 0.0 & 0.0 & 0.0 & 0.0 & 0.0 & 0.0 & 0.0 & 0.0 & 0.0 & 0.0 \\
\hline
\end{tabular}


108 Table. 5. The values of input parameters measured in bottled water samples (Continued.)

\begin{tabular}{|c|c|c|c|c|c|c|c|c|c|c|c|c|c|c|c|c|c|}
\hline \multirow{2}{*}{ Parameter } & \multicolumn{4}{|c|}{ Sample No. } & \multirow[b]{2}{*}{20} & \multirow[b]{2}{*}{21} & \multirow[b]{2}{*}{22} & \multirow[b]{2}{*}{23} & \multirow[b]{2}{*}{24} & \multirow[b]{2}{*}{25} & \multirow[b]{2}{*}{26} & \multirow[b]{2}{*}{27} & \multirow[b]{2}{*}{28} & \multirow[b]{2}{*}{29} & \multirow[b]{2}{*}{30} & \multirow[b]{2}{*}{ Mean } & \multirow[b]{2}{*}{ SD } \\
\hline & 16 & 17 & 18 & 19 & & & & & & & & & & & & & \\
\hline $\mathrm{NO}_{3}(\mathrm{mg} / \mathrm{L})$ & 16.5 & 18.2 & 15.5 & 5.0 & 3.2 & 2.6 & 17.7 & 9.2 & 19.2 & 13.7 & 18.4 & 24.7 & 14.3 & 3.3 & 1.3 & 10.54 & 7.81 \\
\hline $\mathrm{NO}_{2}(\mathrm{mg} / \mathrm{L})$ & 0.0 & 0.1 & 0.0 & 0.1 & 0.1 & 0.1 & 0.0 & 0.1 & 0.0 & 0.1 & 0.1 & 0.0 & 0.1 & 0.0 & 0.0 & 0.03 & 0.02 \\
\hline pH & 7.2 & 7.4 & 7.5 & 7.5 & 7.6 & 7.8 & 7.6 & 7.5 & 7.3 & 7.5 & 7.3 & 7.4 & 7.5 & 7.2 & 7.2 & 7.30 & 0.31 \\
\hline $\mathbf{F}(\mathrm{mg} / \mathrm{L})$ & 0.2 & 0.1 & 0.1 & 0.3 & 0.1 & 0.0 & 0.2 & 0.0 & 0.1 & 0.2 & 0.2 & 0.4 & 0.1 & 0.0 & 0.1 & 0.23 & 0.18 \\
\hline $\begin{array}{l}\text { Hardness } \\
\left(\mathrm{mgCaCO}_{3} / \mathrm{L}\right)\end{array}$ & 63.7 & 134.0 & 48.4 & 98.4 & 54.7 & 81.5 & $\begin{array}{l}153 . \\
2\end{array}$ & $\begin{array}{l}149 . \\
2\end{array}$ & 117.3 & 73.5 & 80.2 & $\begin{array}{l}143 . \\
5\end{array}$ & 114.5 & 50.6 & 85.5 & 107.34 & 42.99 \\
\hline $\mathrm{Ca}(\mathrm{mg} / \mathrm{L})$ & 15.2 & 20.1 & 13.0 & 25.9 & 14.5 & 14.5 & 19.9 & 33.9 & 23.4 & 22.0 & 28.0 & 17.4 & 19.9 & 14.5 & 15.7 & 19.84 & 7.92 \\
\hline $\operatorname{Mg}(\mathrm{mg} / \mathrm{L})$ & 6.2 & 20.4 & 3.9 & 8.2 & 4.5 & 11.0 & 25.2 & 15.6 & 11.3 & 4.5 & 2.5 & 24.3 & 15.8 & 3.5 & 1.3 & 13.59 & 8.83 \\
\hline $\mathrm{Na}(\mathrm{mg} / \mathrm{L})$ & 23.1 & 64.5 & 42.3 & 1.3 & 4.9 & 38.2 & 22.3 & 11.1 & 15.5 & 48.8 & 29.6 & 61.8 & 2.0 & 5.1 & 17.1 & 23.95 & 20.55 \\
\hline $\mathrm{Cl}(\mathrm{mg} / \mathrm{L})$ & 2.0 & 54.0 & 19.0 & 11.0 & 8.0 & 46.0 & 9.0 & 42.0 & 38.0 & 37.0 & 26.0 & 23.0 & 10.0 & 5.0 & 16.0 & 25.40 & 17.67 \\
\hline $\mathrm{SO}_{4}(\mathrm{mg} / \mathrm{L})$ & 15.0 & 63.0 & 21.0 & 5.0 & 23.0 & 30.0 & 9.0 & 18.0 & 17.0 & 53.0 & 9.0 & 68.0 & 24.0 & 16.0 & 20.0 & 26.48 & 19.54 \\
\hline K (mg/L) & 0.9 & 0.4 & 0.1 & 0.1 & 0.4 & 0.2 & 0.1 & 0.1 & 0.0 & 0.1 & 0.1 & 0.4 & 0.1 & 0.4 & 0.2 & 0.25 & 0.19 \\
\hline $\begin{array}{l}\text { Turbidity } \\
\text { (NTU) }\end{array}$ & 0.0 & 0.1 & 0.3 & 0.0 & 0.0 & 0.0 & 0.0 & 0.0 & 0.1 & 0.1 & 0.0 & 0.2 & 0.0 & 0.2 & 0.1 & 0.09 & 0.08 \\
\hline $\begin{array}{l}\text { TC } \\
(\text { MPN/100mL) }\end{array}$ & 0.0 & 0.0 & 0.0 & 0.0 & 0.0 & 0.0 & 0.0 & 0.0 & 0.0 & 0.0 & 0.0 & 0.0 & 0.0 & 0.0 & 0.0 & 0.00 & 0.00 \\
\hline $\begin{array}{l}\text { FC } \\
(\mathrm{MPN} / \mathbf{1 0 0 m L})\end{array}$ & 0.0 & 0.0 & 0.0 & 0.0 & 0.0 & 0.0 & 0.0 & 0.0 & 0.0 & 0.0 & 0.0 & 0.0 & 0.0 & 0.0 & 0.0 & 0.00 & 0.00 \\
\hline $\mathrm{Pb}(\mu \mathrm{g} / \mathrm{L})$ & 2.2 & 2.2 & 2.2 & 2.2 & 2.2 & 2.2 & 2.2 & 2.2 & 2.2 & 2.2 & 2.2 & 2.2 & 2.2 & 2.2 & 2.2 & 2.20 & 0.00 \\
\hline Hg $(\mu \mathrm{g} / \mathrm{L})$ & 0.4 & 0.4 & 0.4 & 0.4 & 0.4 & 0.4 & 0.4 & 0.4 & 0.4 & 0.4 & 0.4 & 0.4 & 0.4 & 0.4 & 0.4 & 0.40 & 0.00 \\
\hline $\mathrm{Cd}(\mu \mathrm{g} / \mathrm{L})$ & 0.1 & 0.1 & 0.1 & 0.1 & 0.1 & 0.1 & 0.1 & 0.1 & 0.1 & 0.1 & 0.1 & 0.1 & 0.1 & 0.1 & 0.1 & 0.05 & 0.00 \\
\hline $\mathrm{Ni}(\mu \mathrm{g} / \mathrm{L})$ & 12.4 & 3.4 & 3.0 & 1.0 & 9.2 & 0.9 & 1.7 & 1.7 & 1.3 & 0.4 & 0.6 & 3.0 & 1.7 & 9.8 & 1.5 & 2.81 & 2.79 \\
\hline $\operatorname{As}(\mu \mathrm{g} / \mathrm{L})$ & 0.2 & 0.2 & 0.2 & 0.2 & 0.2 & 0.2 & 0.2 & 0.2 & 0.2 & 0.2 & 0.2 & 0.2 & 0.2 & 0.2 & 0.2 & 0.20 & 0.00 \\
\hline $\mathrm{CO}(\mathrm{mg} / \mathrm{L})$ & 0.0 & 0.0 & 0.0 & 0.0 & 0.0 & 0.0 & 0.0 & 0.0 & 0.0 & 0.0 & 0.0 & 0.0 & 0.0 & 0.0 & 0.0 & 0.04 & 0.00 \\
\hline $\mathrm{Fe}(\mathrm{mg} / \mathrm{L})$ & 0.2 & 0.2 & 0.2 & 0.2 & 0.2 & 0.2 & 0.2 & 0.6 & 0.2 & 0.2 & 3.1 & 0.3 & 0.2 & 0.8 & 0.2 & 0.44 & 0.65 \\
\hline $\operatorname{Mn}(\mathrm{mg} / \mathrm{L})$ & 0.1 & 0.1 & 0.1 & 0.1 & 0.1 & 0.1 & 0.1 & 0.1 & 0.1 & 0.1 & 0.1 & 0.1 & 0.1 & 0.1 & 0.1 & 0.06 & 0.00 \\
\hline $\mathrm{Zn}(\mathrm{mg} / \mathrm{L})$ & 0.0 & 0.0 & 0.0 & 0.0 & 0.0 & 0.0 & 0.0 & 0.0 & 0.0 & 0.0 & 0.0 & 0.0 & 0.0 & 0.0 & 0.0 & 0.02 & 0.09 \\
\hline
\end{tabular}


$\mathrm{Cu}(\mathrm{mg} / \mathrm{L})$

0.0

0.0

$\begin{array}{lll}0.0 & 0.0 \quad 0.0\end{array}$

$0.0 \quad 0.0$
0

$0.0 \quad 0.0$

0.0

$0.0 \quad 0.0$

0.0

0.0

0.0

0.02 
110 Table. 6. The BWQI scores obtained for the 30 studied samples

\begin{tabular}{|c|c|c|c|c|c|c|c|c|c|c|c|c|c|c|c|}
\hline \multirow{2}{*}{ Parameter } & \multicolumn{15}{|c|}{ Sample No. } \\
\hline & 1 & 2 & 3 & 4 & 5 & 6 & 7 & 8 & 9 & $\mathbf{1 0}$ & 11 & 12 & 13 & 14 & 15 \\
\hline $\mathrm{NO}_{3}(\mathrm{mg} / \mathrm{L})$ & 54.28 & 49.13 & 58.16 & 73.31 & 81.18 & 84.47 & 50.56 & 61.22 & 46.23 & 58.72 & 48.38 & 37.93 & 59.16 & 80.71 & 91.59 \\
\hline $\mathrm{NO}_{2}(\mathrm{mg} / \mathrm{L})$ & 45.6 & 40 & 56.18 & 36.18 & 40 & 38.04 & 45.6 & 26.84 & 42.4 & 38.04 & 38.04 & 49.6 & 38.04 & 56.18 & 42.4 \\
\hline pH & 100 & 100 & 100 & 100 & 100 & 100 & 100 & 100 & 100 & 100 & 100 & 100 & 100 & 100 & 100 \\
\hline $\mathbf{F}(\mathrm{mg} / \mathrm{L})$ & 46 & 24 & 20 & 58 & 12 & 4 & 36 & 6 & 28 & 32 & 32 & 80 & 16 & 8 & 18 \\
\hline $\begin{array}{l}\text { Hardness } \\
\left(\mathrm{mgCaCO}_{3} / \mathrm{L}\right)\end{array}$ & 100 & 100 & 96.84 & 100 & 100 & 100 & 100 & 100 & 100 & 100 & 100 & 100 & 100 & 100 & 100 \\
\hline $\mathrm{Ca}(\mathrm{mg} / \mathrm{L})$ & 30.42 & 40 & 26.03 & 51.76 & 29 & 29 & 39.8 & 67.96 & 56.72 & 44 & 56 & 34.69 & 39.79 & 29 & 31.3 \\
\hline $\operatorname{Mg}(\mathrm{mg} / \mathrm{L})$ & 62.37 & 100 & 38.66 & 82.12 & 45 & 100 & 100 & 100 & 100 & 45 & 25 & 100 & 100 & 35 & 100 \\
\hline $\mathrm{Na}(\mathrm{mg} / \mathrm{L})$ & 46.14 & 100 & 84.59 & 2.73 & 9.96 & 76.31 & 44.64 & 22.27 & 30.98 & 48.78 & 59.21 & 100 & 4.04 & 10.26 & 34.23 \\
\hline $\mathrm{Cl}(\mathrm{mg} / \mathrm{L})$ & 2 & 54 & 19 & 11 & 8 & 46 & 9 & 42 & 38 & 37 & 26 & 23 & 10 & 5 & 16 \\
\hline $\mathrm{SO}_{4}(\mathrm{mg} / \mathrm{L})$ & 15 & 63 & 21 & 5 & 23 & 30 & 9 & 18 & 17 & 53 & 9 & 68 & 24 & 16 & 20 \\
\hline $\mathrm{K}(\mathbf{m g} / \mathbf{L})$ & 19.32 & 8.67 & 1.93 & 1.37 & 8.09 & 3.6 & 2.03 & 2.79 & 0.62 & 1.78 & 2.05 & 7.47 & 1.89 & 8.10 & 3.54 \\
\hline Turbidity (NTU) & 97.63 & 90.95 & 80.61 & 97.63 & 99.2 & 97.63 & 96.86 & 97.63 & 96.10 & 93.11 & 98.42 & 88.86 & 96.86 & 53.12 & 95.34 \\
\hline TC (MPN/100mL) & 100 & 100 & 100 & 100 & 100 & 100 & 100 & 100 & 100 & 100 & 100 & 100 & 100 & 100 & 100 \\
\hline FC (MPN/ & 100 & 100 & 100 & 100 & 100 & 100 & 100 & 100 & 100 & 100 & 100 & 100 & 100 & 100 & 100 \\
\hline $\mathrm{Pb}(\mu \mathrm{g} / \mathrm{L})$ & 59.08 & 59.08 & 59.08 & 59.08 & 59.08 & 59.08 & 59.08 & 59.08 & 59.08 & 59.08 & 59.08 & 59.08 & 59.08 & 59.08 & 59.08 \\
\hline $\mathrm{Hg}(\mu \mathrm{g} / \mathrm{L})$ & 84.3 & 84.30 & 84.3 & 84.3 & 84.3 & 84.3 & 84.3 & 84.3 & 84.3 & 84.3 & 84.3 & 84.3 & 84.3 & 84.3 & 84.3 \\
\hline $\mathrm{Cd}(\mu \mathrm{g} / \mathrm{L})$ & 95.24 & 95.24 & 95.24 & 95.24 & 95.24 & 95.24 & 95.24 & 95.24 & 95.24 & 95.24 & 95.24 & 95.24 & 95.24 & 95.24 & 95.24 \\
\hline $\mathrm{Ni}(\mu \mathrm{g} / \mathrm{L})$ & 60.75 & 84.56 & 86.24 & 94.97 & 66.66 & 95.85 & 92.02 & 91.89 & 93.56 & 98 & 97.05 & 86.5 & 91.88 & 65.35 & 92.94 \\
\hline As $(\mu \mathrm{g} / \mathrm{L})$ & 95.36 & 95.36 & 95.36 & 95.36 & 95.36 & 95.36 & 95.36 & 95.36 & 95.36 & 95.36 & 95.36 & 95.36 & 95.36 & 95.36 & 95.36 \\
\hline $\mathrm{CO}(\mathrm{mg} / \mathrm{L})$ & 0 & 0.22 & 0.22 & 0.22 & 0.22 & 0.22 & 0.22 & 0.22 & 0.22 & 0.22 & 0.22 & 0.22 & 0.22 & 0.22 & 0.22 \\
\hline $\mathrm{Fe}(\mathrm{mg} / \mathrm{L})$ & 0.16 & 0.2 & 0.16 & 0.16 & 0.16 & 0.16 & 0.16 & 0.61 & 0.16 & 0.16 & 3.11 & 0.26 & 0.16 & 0.75 & 0.16 \\
\hline Mn ( & 0.07 & 0.07 & 0.07 & 0.07 & 0.07 & 0.07 & 0.07 & 0.07 & 0.07 & 0.07 & 0.07 & 0.07 & 0.07 & 0.07 & 0.07 \\
\hline $\mathrm{Zn}(\mathrm{mg} / \mathrm{L})$ & 0.32 & 0.59 & 0.74 & 0.72 & 0.54 & 0.99 & 1.19 & 0.57 & 0.6 & 1.09 & 0.62 & 0.46 & 0.54 & 1.5 & 0.51 \\
\hline $\mathrm{Cu}(\mathrm{mg} / \mathrm{L})$ & 4.76 & 4.62 & 4.74 & 4.73 & 4.78 & 4.84 & 4.75 & 4.57 & 4.66 & 4.82 & 4.61 & 4.80 & 4.57 & 5.14 & 4.72 \\
\hline BWQI & 63.01 & 70.75 & 66.27 & 65.01 & 61.52 & 70.56 & 65.68 & 66.11 & 66.65 & 70.15 & 66.41 & 70.31 & 62.91 & 61.21 & 66.98 \\
\hline
\end{tabular}


112 Table. 6. The BWQI scores obtained for the 30 studied samples (Continued.)

\begin{tabular}{|c|c|c|c|c|c|c|c|c|c|c|c|c|c|c|c|}
\hline \multirow{2}{*}{ Parameter } & \multicolumn{15}{|c|}{ Sample No. } \\
\hline & 16 & 17 & 18 & 19 & 20 & 21 & 22 & 23 & 24 & 25 & 26 & 27 & 28 & 29 & 30 \\
\hline $\mathrm{NO}_{3}(\mathrm{mg} / \mathrm{L})$ & 78.46 & 58.87 & 37.74 & 63.39 & 74 & 40.16 & 56.03 & 78.02 & 75.06 & 93.54 & 53.65 & 87.68 & 74.77 & 82.76 & 92.38 \\
\hline $\mathrm{NO}_{2}(\mathrm{mg} / \mathrm{L})$ & 56.18 & 40 & 26.84 & 82.4 & 82.4 & 90.60 & 75.40 & 75.4 & 70.13 & 76.70 & 72.35 & 73.74 & 72.35 & 74.98 & 76.05 \\
\hline pH & 100 & 100 & 100 & 100 & 100 & 100 & 100 & 100 & 88.27 & 78.67 & 94.67 & 100 & 87.73 & 78.67 & 100 \\
\hline $\mathbf{F}(\mathrm{mg} / \mathrm{L})$ & 20 & 22 & 72 & 60 & 100 & 44 & 56 & 100 & 64 & 24 & 100 & 48 & 46 & 78 & 30 \\
\hline $\begin{array}{l}\text { Hardness } \\
\left(\mathrm{mgCaCO}_{3} / \mathrm{L}\right)\end{array}$ & 100 & 100 & 100 & 100 & 100 & 75.73 & 100 & 100 & 100 & 72.22 & 100 & 95.86 & 100 & 100 & 100 \\
\hline $\mathrm{Ca}(\mathrm{mg} / \mathrm{L})$ & 49.08 & 61.45 & 49.59 & 58.01 & 56.57 & 63.23 & 15.13 & 37.75 & 46.25 & 14.27 & 35.03 & 11.89 & 46.19 & 49.29 & 1.29 \\
\hline $\operatorname{Mg}(\mathrm{mg} / \mathrm{L})$ & 100 & 100 & 89.95 & 100 & 81.2 & 31.07 & 100 & 100 & 100 & 44.44 & 100 & 80.33 & 100 & 100 & 100 \\
\hline $\mathrm{Na}(\mathrm{mg} / \mathrm{L})$ & 55.33 & 8.22 & 63.98 & 17.36 & 15.14 & 62.37 & 100 & 7.17 & 4.89 & 77.35 & 100 & 26.94 & 55.52 & 6.02 & 4.59 \\
\hline $\mathrm{Cl}(\mathrm{mg} / \mathrm{L})$ & 42 & 13 & 10 & 11 & 10 & 50 & 52 & 9 & 19 & 65 & 27 & 17 & 56 & 17 & 18 \\
\hline $\mathrm{SO}_{4}(\mathrm{mg} / \mathrm{L})$ & 11 & 29 & 22 & 23 & 3 & 78 & 67 & 26 & 10 & 22.5 & 29.3 & 13.44 & 9.53 & 19.6 & 40.2 \\
\hline $\mathrm{K}(\mathrm{mg} / \mathrm{L})$ & 3.79 & 8.21 & 4.33 & 4.4 & 2.74 & 7.56 & 5.4 & 2.97 & 2.19 & 4.52 & 7.49 & 2.54 & 4.01 & 2.9 & 13.47 \\
\hline Turbidity (NTU) & 99.2 & 95.34 & 95.34 & 96.86 & 98.42 & 94.59 & 98.42 & 95.34 & 90.25 & 91.66 & 85.54 & 74.14 & 94.59 & 93.11 & 92.38 \\
\hline TC (MPN/100mL) & 100 & 100 & 100 & 100 & 100 & 100 & 100 & 100 & 100 & 100 & 100 & 100 & 100 & 100 & 100 \\
\hline FC (MPN/100mL) & 100 & 100 & 100 & 100 & 100 & 100 & 100 & 100 & 100 & 100 & 100 & 100 & 100 & 100 & 100 \\
\hline $\mathrm{Pb}(\mu \mathrm{g} / \mathrm{L})$ & 59.08 & 59.08 & 59.08 & 59.08 & 59.08 & 59.08 & 59.08 & 59.08 & 59.08 & 59.08 & 59.08 & 59.08 & 59.08 & 59.08 & 59.08 \\
\hline $\mathrm{Hg}(\mu \mathrm{g} / \mathrm{L})$ & 84.3 & 84.3 & 84.3 & 84.3 & 84.3 & 84.3 & 84.30 & 84.3 & 84.3 & 84.3 & 84.3 & 84.3 & 84.3 & 84.3 & 84.3 \\
\hline $\mathrm{Cd}(\mu \mathrm{g} / \mathrm{L})$ & 95.24 & 95.24 & 95.24 & 95.24 & 95.24 & 95.24 & 95.24 & 95.24 & 95.24 & 95.24 & 95.24 & 95.24 & 95.24 & 95.24 & 95.24 \\
\hline $\mathrm{Ni}(\mu \mathrm{g} / \mathrm{L})$ & 94.07 & 79.5 & 86.08 & 84.72 & 90.33 & 91 & 87.93 & 92.88 & 90.06 & 97.39 & 83.9 & 90.18 & 93.35 & 90.01 & 98.58 \\
\hline As $(\mu \mathrm{g} / \mathrm{L})$ & 95.36 & 95.36 & 95.36 & 95.36 & 95.36 & 95.36 & 95.36 & 95.36 & 95.36 & 95.36 & 95.36 & 95.36 & 95.36 & 95.36 & 95.36 \\
\hline $\mathrm{CO}(\mathrm{mg} / \mathrm{L})$ & 0.22 & 0.22 & 0.22 & 0.22 & 0.22 & 0.22 & 0.22 & 0.22 & 0.22 & 0.22 & 0.22 & 0.22 & 0.22 & 0.22 & 0.22 \\
\hline $\mathrm{Fe}(\mathrm{mg} / \mathrm{L})$ & 0.16 & 0.16 & 0.16 & 0.47 & 0.16 & 0.16 & 0.16 & 0.16 & 0.16 & 0.81 & 0.63 & 0.7 & 0.23 & 0.16 & 2.29 \\
\hline $\operatorname{Mn}(\mathrm{mg} / \mathrm{L})$ & 0.07 & 0.07 & 0.07 & 0.07 & 0.07 & 0.07 & 0.07 & 0.07 & 0.07 & 0.08 & 0.07 & 0.07 & 0.07 & 0.07 & 0.07 \\
\hline $\mathrm{Zn}(\mathrm{mg} / \mathrm{L})$ & 0.44 & 0.61 & 0.73 & 0.63 & 0.87 & 0.54 & 0.82 & 0.5 & 0.44 & 51.09 & 0.68 & 1.14 & 0.68 & 0.46 & 4.49 \\
\hline $\mathrm{Cu}(\mathrm{mg} / \mathrm{L})$ & 4.74 & 4.78 & 4.62 & 4.95 & 4.61 & 4.70 & 4.86 & 4.84 & 4.87 & 4.52 & 4.70 & 4.79 & 4.93 & 4.77 & 4.87 \\
\hline BWQI & 70.78 & 63.65 & 65.93 & 68.23 & 69.67 & 71.20 & 73.88 & 68.86 & 66.69 & 71.99 & 72.36 & 66.45 & 71.98 & 67.63 & 66.77 \\
\hline
\end{tabular}
113 


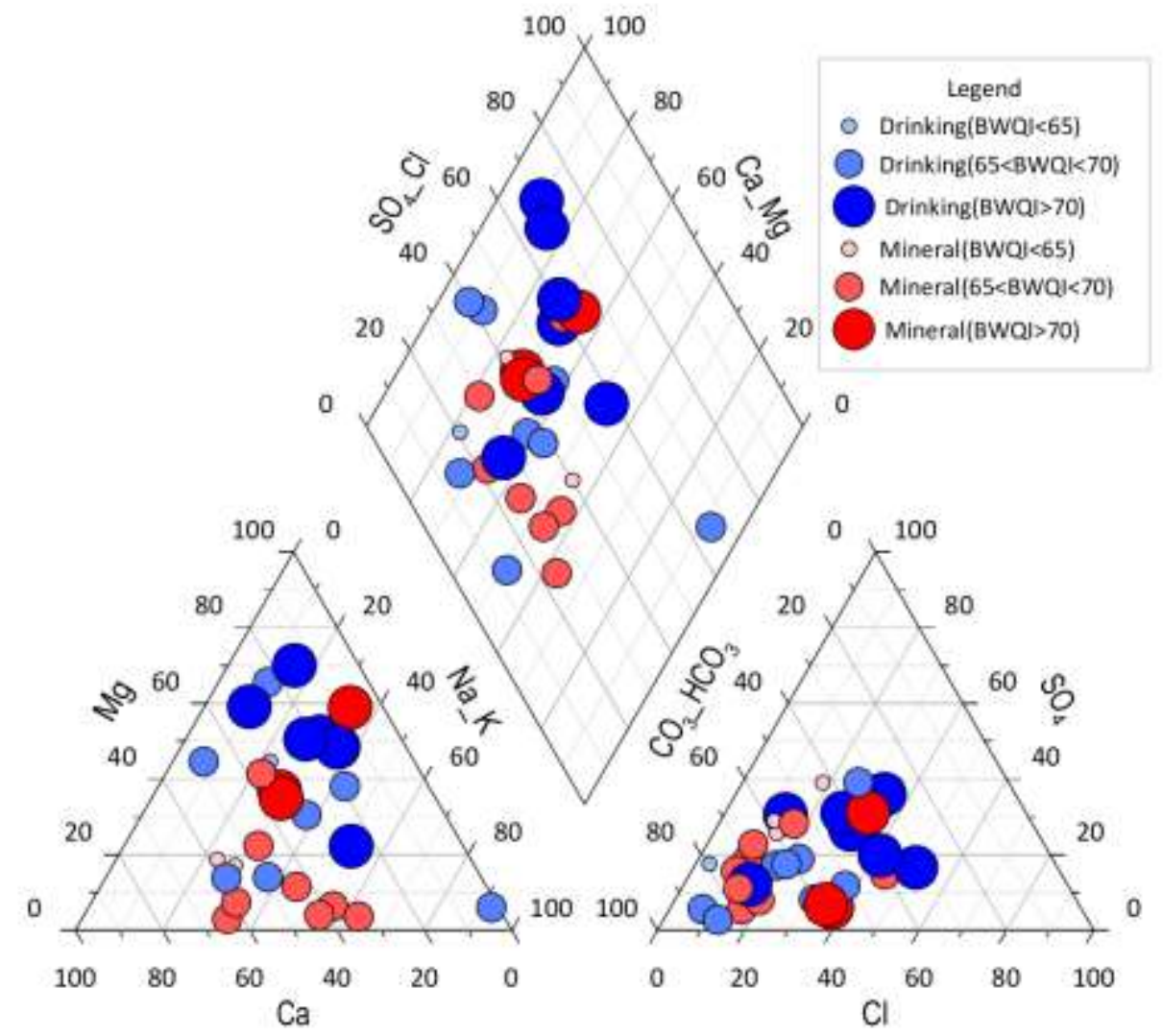

115

116 Figure. 4. BWQI scores comparison between drinking and mineral bottled water samples.

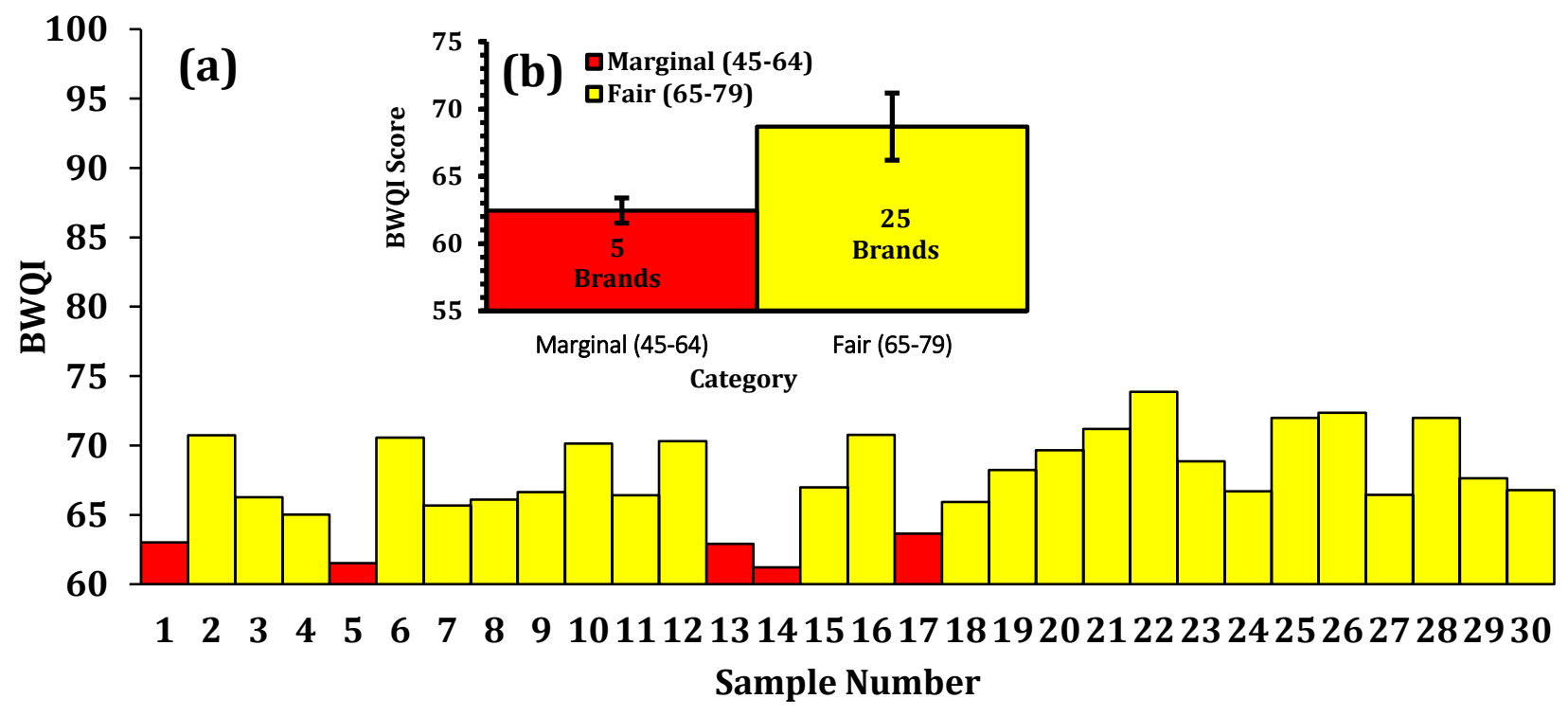

118 Figure. 5. BWQI scores obtained for 30 samples taken from Hamadan province retails (a), the

119 number of brands belonged to the assigned categories (b). 
120 The Shapiro-Wilk test results showed the non-significant $\mathrm{P}$ values, 0.78 and 0.12 for the

121 mineral and drinking water samples, respectively, revealing that the values obtained from the

122 measurement of bottled water samples have the normal distribution. Furthermore, the F-test

123 value of 0.29 represents the equality of variances regarding both the drinking and mineral

124 bottled water samples. However, the results of two independent samples T-test indicated that

125 the difference between BWQI scores obtained from drinking bottled water and mineral

126 drinking water samples was not significant $\left(\mathrm{P}_{\text {value }}=0.2\right)$. Fig. 6 presents the differences between

127 the BWQI scores obtained for mineral and drinking bottled water samples. As shown, the

128 scores acquired for the bottled drinking water samples are slightly higher than those assigned

129 to the mineral drinking water samples. Better scores obtained for the drinking bottled water

130 samples are mainly due to low contents of $\mathrm{NO}_{3}, \mathrm{NO}_{2}, \mathrm{Fe}, \mathrm{Mn}, \mathrm{Cu}$, and $\mathrm{Zn}$ in these samples

131 which are exploited from public distribution systems having the rigorous standards on

132 municipal water treatment plants for providing safe water. The mineral bottled water samples

133 mainly obtain from the private springs of provinces denoted in Table 1 located in mountainous

134 areas in the neighboring agricultural regions. They are mainly affected by the mineral contents

135 of sedimentary rocks and $\mathrm{NO}_{3}$ leaks from fertilizers used in the agricultural activities.

136 Furthermore, the private springs may have not involved the rigorous surveillance system like

137 those enforced in the public water distribution systems (Viscusi, Huber et al. 2015). 


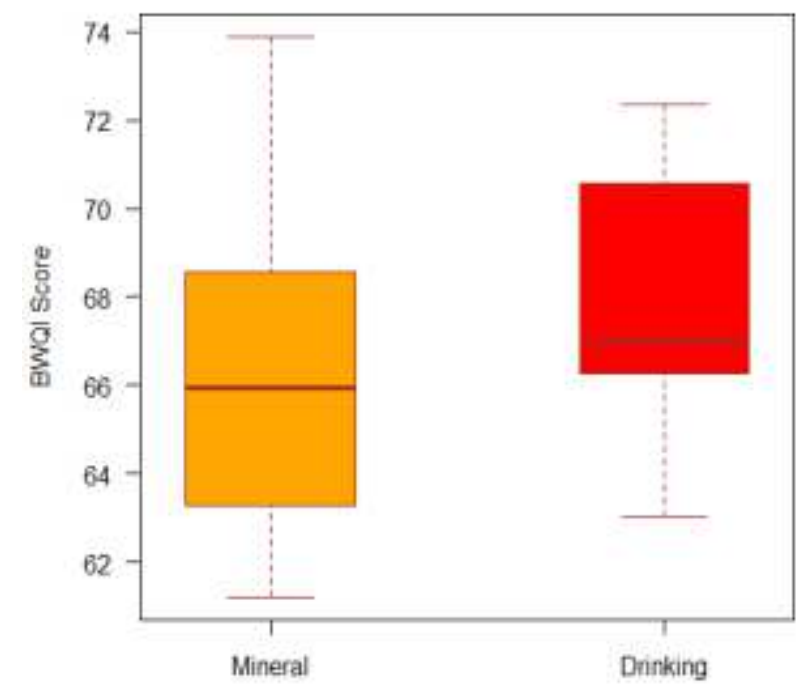

138

139 Figure. 6. BWQI scores comparison between drinking and mineral bottled water samples.

140 An innovative method for defuzzifing the output values $y_{p, i}$ and $y_{p, j}$ was introduced adopted

141 from an approach used for determining the acting point of the resultant force on a free-end

142 cantilever beam (Hibbeler 2004). In Fig. 3.b, if the X-axis be supposed as a cantilever having

143 a fixed end at zero, so that, the resultant value of $y_{p, r}$ can be obtained using Eq. 8.

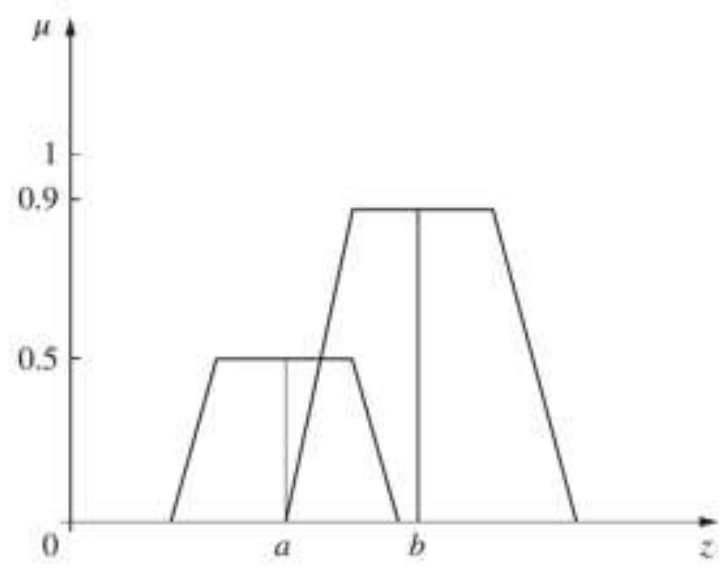

Figure 7. weighted average method of defuzzification (Ross 2004).

146 Four principal methods for defuzzifying fuzzy output functions (membership functions), were suggested during recent years including the max membership principle, centroid method, 
148 weighted average method, and mean max membership (Ross 2004). All the above-mentioned 149 methods determine a defuzzified representative value regarding the geometric shape of the 150 fuzzy output membership functions like those observed in Fig. 7. For example, the centroid 151 method yields a defuzzified value which is the center of gravity of the confined geometric 152 shape under the curves (Yager and Zadeh 2012). In case of obtaining an index, like those performed in our work, the output membership functions comprise the $\mathrm{X}$-axis graded between 0 and 100. Accordingly, the output index does not merely depend on the value obtained from the area under the confined geometric shape but also relies on the magnitude of assigning membership function. Consequently, the values of membership functions $\mu\left(x_{p, i}\right)$ and $\mu\left(x_{p, j}\right)$ can be considered as the weights of output values $y_{p, i}$ and $y_{p, j}$, respectively. Comparing with a one-side fixed cantilever, the membership function $\mu\left(x_{p}\right)$ can be assumed as force $(\mathrm{F})$ and the output value $y_{p, j}$ is the distance (D) (Hibbeler 2004). However, significant uncertainty in the score (output) values of water quality indices can exist which would not be considered (Xu, Wang et al. 2015; Zheng and Han 2016). Here, we attempt to involve the uncertainty nature of the BWQI input parameters to apply the appropriate distribution regarding the output score.

164 Fig. 8 shows the uncertainty analysis of BWQI scores using a Monte Carlo simulation analysis.

165 Output results of the simulation obtained from $10^{4}$ trials, proposed the beta distribution to 166 predict the probability of values versus BWQI scores. As shown, regardless of the type of 167 bottled water (drinking or mineral), the mean score of BWQI obtained from the 30 drinking water samples was 67.89 2.29 . Results also display that the BWQI scores obtained from samples will be laid between 64 and 74 under the certainty of $95 \%$. 


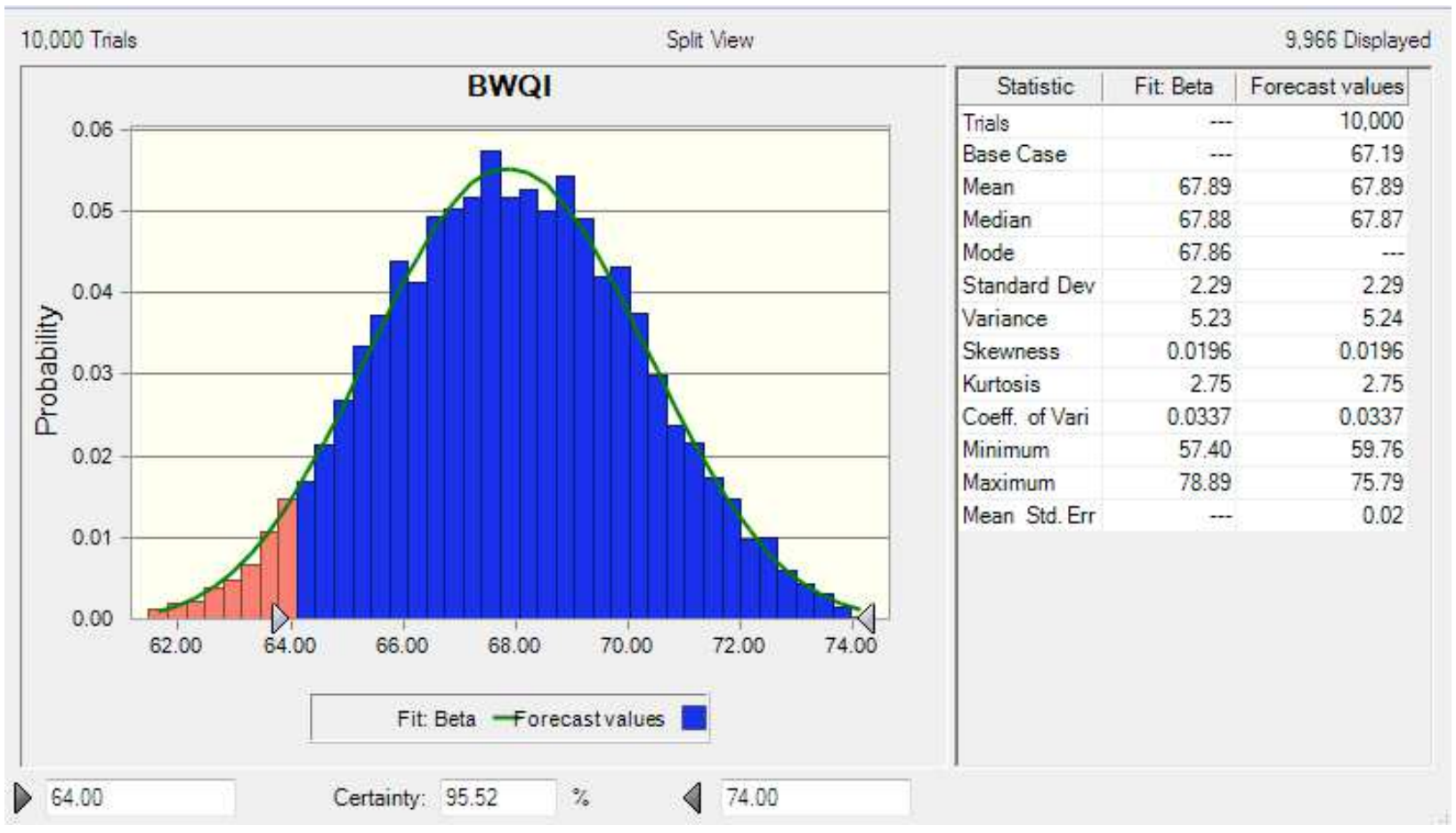

172 Figure 8. Uncertainty analysis of BWQI scores.

173 The sensitivity analysis of BWQI was conducted applying the Monte Carlo algorithm. BWQI

174 involves 24 input parameters so that only the parameters acquired the sensitivity values more

175 than $2 \%$ appeared in Fig. 9 and the other parameters were not shown here. The sensitivity

176 analysis demonstrated that withdrawing each of the input parameters $\mathrm{NO}_{3}, \mathrm{Na}$, hardness, and

$177 \mathrm{NO}_{2}$ from $\mathrm{BWQI}$ tends to more than $10 \%$ change in the BWQI original form, which comprises

178 all input parameters. The BWQI original score has $+15 \%$ sensitivity to $\mathrm{NO}_{3}$ whereas it reveals

179 less than $-10 \%$ sensitivity to the input parameters $\mathrm{Na}$ and hardness. 


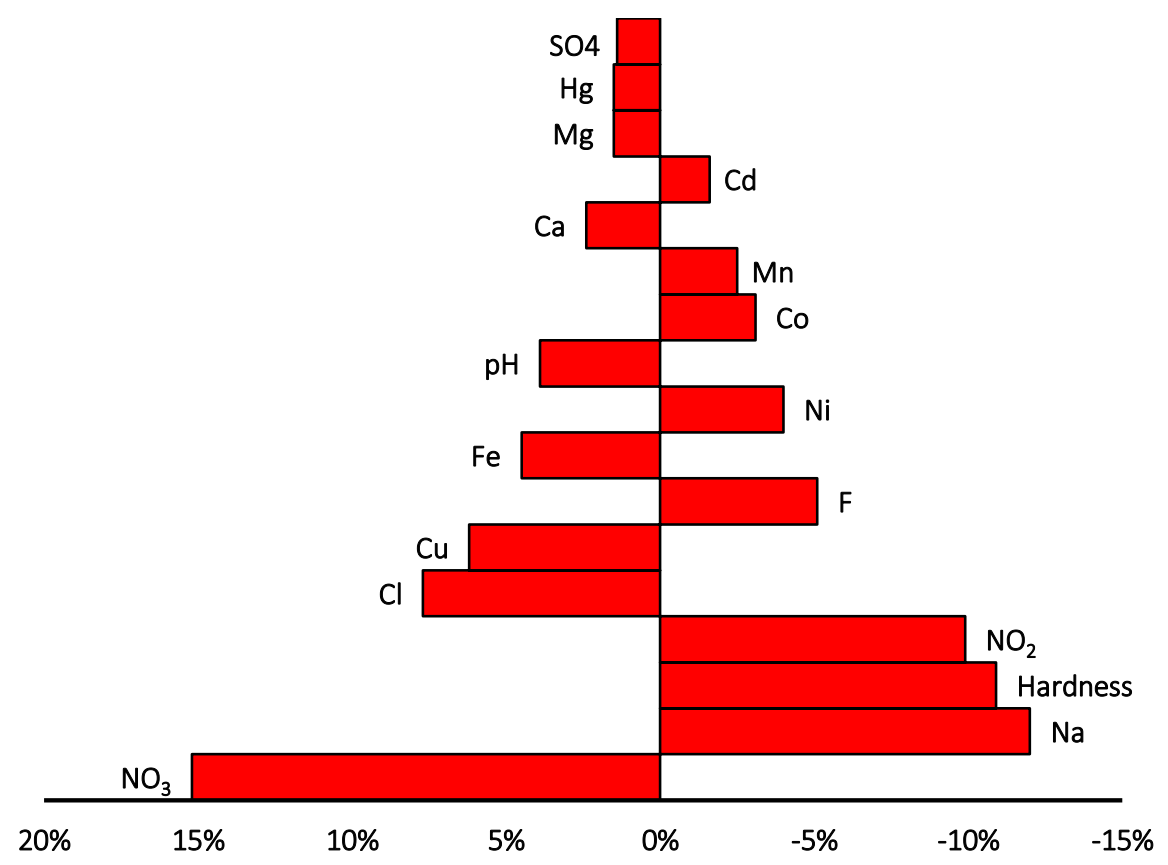

181 Figure 9. Sensitivity analysis of BWQI parameters.

182

183

\section{Conclusions}

- The BWQI was developed for the judgment of bottled water quality based on the fuzzy inference system.

- BWQI is the first attempt to introduce a bottled water quality index by an innovative fuzzy inference method.

- All bottled water brands available in the retail market of the Hamadan province were used to evaluate the index known as bottled water quality index (BWQI).

- Various parameters were used as the input factors aiming to consider physiochemical properties, dietary issues, toxic effects, and microbial hazards.

- A new method to produce the sub-index values from the fuzzy numbers applied in the inference system was developed.

- Piper diagram prepared based on 30 measured samples depicted that most of the bottled water in the Iranian retail market is classified in the bicarbonate-calcium category. 
- Uncertainty and sensitivity analyses were developed to indicate the range of BWQI having more than $95 \%$ of certainty and to determine the impact of omitting each input parameter on the output index, respectively.

\section{Acknowledgments}

The authors acknowledge the Hamadan University of Medical Sciences for financial funding (Number of Grant: 9705022492) and charge to instruments in this work.

Authors Contributions All authors contributed to the study conception and design. Material preparation, data collection and analysis were performed by Mohammad Khazaei and Ensieh Komijani. Ghorban Asgari and Abdolmotaleb Seid-Mohammadiwrote the first draft of the manuscript, and all authors commented on previous versions of the manuscript. All authors read and approved the final manuscript.

Funding Hamadan University of Medical Sciences (Number of Grant: 9705022492)

Data Availability Available upon request.

Ethical Responsibilities The manuscript complies with all the ethical requirements; the paper was not summited to any journal at a time. All the sources and contributors were acknowledged properly.

Consent to Participate I am very much to participate in the task for the journal including reviewing similar works.

Consent to Publish I have fully agreed to publish the manuscript "Assessment the quality of bottled drinking water through Mamdani Fuzzy water quality index" after peer review on the journal of water resources management.

Conflict of Interest/Competing Interests The authors declare that they have no known competing financial interests or personal relationships that could have appeared to influence the work reported in this paper. 


\section{References}

221

222

223

224

225

226

227

228

229

230

231

232

Abtahi, M., K. Yaghmaeian, et al. (2016). "An innovative drinking water nutritional quality index (DWNQI) for assessing drinking water contribution to intakes of dietary elements: A national and sub-national study in Iran." Ecological Indicators 60(Supplement C): 367-376.

Ahmed, T., K. Rashid, et al. (2016). "Nutrient minerals in commercially available bottled waters of Bangladesh: dietary implications." Bangladesh journal of scientific and industrial research 51(2): 111-120.

Alimentarius, C. (2001). "General standard for bottled/packaged drinking waters (Other than natural mineral waters). Codex Stan 227-2001." Joint FAO/WHO Food Standards Program, FAO, Rome Google Scholar.

Alimentarius, C., Ed. (2008). Codex standard for natural mineral waters. Codex FAO.

American Public Health Association, A. (1995). Standard methods for the examination of

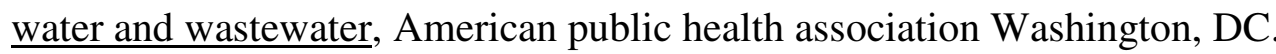

Bahmani, O. and S. Palangi (2018). "Assessment of Groundwater Quality in Human Health Risk, Agriculture and Industry with the Qualitative Indices in the Bahar Plain, West Iran." Asian Journal of Water, Environment and Pollution 15(4): 81-88.

Chang, N.-B., H.-W. Chen, et al. (2001). "Identification of river water quality using the fuzzy synthetic evaluation approach." Journal of environmental management 63(3): 293305.

Council, N. R. (1989). Recommended dietary allowances, National Academies Press.

Council, N. R. (2012). Review of the EPA's Economic Analysis of Final Water Quality $\underline{\text { Standards for Nutrients for Lakes and Flowing Waters in Florida, National Academies }}$ Press. 
Dinelli, E., A. Lima, et al. (2010). "Hydrogeochemical analysis on Italian bottled mineral waters: Effects of geology." Journal of Geochemical Exploration 107(3): 317-335.

DOE (2010). " Iran Water Quality Index (IRWQI)." Dot Environment (Ed.), Tehran, Iran.

Eslami, F., K. Yaghmaeian, et al. (2019). "An integrated evaluation of groundwater quality using drinking water quality indices and hydrochemical characteristics: a case study

Espejo-Herrera, N., M. Kogevinas, et al. (2013). "Nitrate and trace elements in municipal and bottled water in Spain." Gaceta Sanitaria 27(2): 156-160.

Espejo-Herrera, N., M. Kogevinas, et al. (2013). "Nitrate and trace elements in municipal and bottled water in Spain." Gaceta Sanitaria 27(2): 156-160.

Fard, R. F., A. H. Mahvi, et al. (2014). "Fluoride concentrations in bottled drinking water available in Najaf and Karbala, Iraq." Fluoride 47(3): 249-252.

Felipe-Sotelo, M., E. Henshall-Bell, et al. (2015). "Comparison of the chemical composition

Gharibi, H., A. H. Mahvi, et al. (2012). "A novel approach in water quality assessment based on fuzzy logic." Journal of Environmental Management 112: 87-95.

Gharibi, H., M. H. Sowlat, et al. (2012). "Development of a dairy cattle drinking water quality index (DCWQI) based on fuzzy inference systems." Ecological Indicators 20: 228-237.

Gitau, M. W., J. Chen, et al. (2016). "Water Quality Indices as Tools for Decision Making and Management." 30(8): 2591-2610.

Haraoui, N. E., T. Tao, et al. (2014). "Trace elements in spring and purified bottled water: A case study in Shanghai." Fresenius Environmental Bulletin 23(5): 1203-1208.

268 Hibbeler, R. (2004). Statics, Pearson Education Inc. 
Horton, R. K. (1965). "An index number system for rating water quality." Journal of Water Pollution Control Federation 37(3): 300-306.

Hounslow, A. (2018). Water quality data: analysis and interpretation, CRC press.

IBWA. (2018/07/08). "Iranian Bottled Water Association." from http://www.irbwa.com/.

Icaga, Y. (2007). "Fuzzy evaluation of water quality classification." Ecological Indicators 7(3): 710-718.

Katz, D. L., V. Y. Njike, et al. (2009). "The Stratification of Foods on the Basis of Overall Nutritional Quality: The Overall Nutritional Quality Index." American Journal of Health Promotion 24(2): 133-143.

Khazaei, M., A. H. Mahvil, et al. (2013). "Dental caries prevalence among schoolchildren in urban and rural areas of qom province, central part of Iran." Middle East Journal of Scientific Research 18(5): 584-591.

Khazaei, M., A. R. Rahmani, et al. (2019). "Development and Application of a Potentiometric Hg2+-Imprinted Polymer/graphitic Carbon Nitride/Carbon Paste Electrode." Analytical \& Bioanalytical Electrochemistry 11(4): 535-545.

Mohebbi, M.-R., A. Montazeri, et al. (2013). "Development of a modified drinking water quality index (MDWQI) and its application for assessing water quality in groundwater resources of Iran." Iranian Journal of Health and Environment 6(2): 187-200.

Mohebbi, M. R., R. Saeedi, et al. (2013). "Assessment of water quality in groundwater resources of Iran using a modified drinking water quality index (DWQI)." Ecological indicators 30: 28-34.

Mosaferi, M., Y. Hajizadeh, et al. (2007). "Importance of water quality control in food safety, case study: drinking, dairy and caning industries of east Azerbaijan." 
Mukhopadhay, B., M. Majumder, et al. (2009). "Verification of filter efficiency of horizontal roughing filter by Weglin's design criteria and Artificial Neural Network." Drinking Water Engineering and Science 2(1): 21-27.

Nabizadeh, R., A. H. Mahvi, et al. (2018). "A fuzzy multi-criteria decision making approach for evaluating the health-care waste treatment alternatives." Environmental Engineering and Management Journal 17(12): 2795-2805.

Nabizadeh, R., A. H. Mahvi, et al. (2018). "A fuzzy multi-criteria decision making approach for evaluating the health-care waste treatment alternatives." Environmental Engineering \& Management Journal (EEMJ) 17(12).

Ocampo-Duque, W., C. Osorio, et al. (2013). "Water quality analysis in rivers with nonparametric probability distributions and fuzzy inference systems: Application to the Cauca River, Colombia." Environment International 52: 17-28.

Organization, W. H. (2005). "Nutrients in drinking water."

Ott, W. R. (1978). "Environmental indices: theory and practice."

Rahman, I. M., S. Barua, et al. (2017). "Quality assessment of the non-carbonated bottled drinking water marketed in Bangladesh and comparison with tap water." Food control 73: $1149-1158$.

Ross, T. J. (2004). Fuzzy logic with engineering applications, Wiley Online Library.

Samadi, M., A. Rahmani, et al. (2009). "Evaluation of chemical quality in 17 brands of Iranian bottled drinking waters." Journal of research in health sciences 9 (2): 25-31.

Selvaraj, K. K., H. Mubarakali, et al. (2016). "Cumulative exposure and dietary risk assessment of phthalates in bottled water and bovine milk samples: A preliminary case study in Tamil Nadu, India." Human and Ecological Risk Assessment: An International Journal 22(5): 1166-1182. 
Shakerkhatibi, M., M. Mosaferi, et al. (2019). "Comprehensive investigation of groundwater quality in the north-west of Iran: Physicochemical and heavy metal analysis." Groundwater for Sustainable Development 8: 156-168.

Silvert, W. (2000). "Fuzzy indices of environmental conditions." Ecological Modelling 130(1): 111-119.

Soleimani, H., O. Nasri, et al. (2018). "Data on drinking water quality using water quality index (WQI) and assessment of groundwater quality for irrigation purposes in Qorveh\&Dehgolan, Kurdistan, Iran." Data in Brief 20: 375-386.

Toma, J., R. Ahmed, et al. (2013). "Application of water quality index for assessment water quality in some bottled water Erbil City, Kurdistan Region, Iraq." Journal of Advanced Laboratory Research in Biology 4(4): 118-124.

Tsakiris, V., D. Alexakis, et al. (2017). "Assessing the quality of bottled water brands using a new water quality index."

UNEP, G. (2007). "Global Drinking Water Quality Index Development and Sensitivity Analysis Report." Ontario, Canada: Water Programme Office.

Uusitalo, L., A. Lehikoinen, et al. (2015). "An overview of methods to evaluate uncertainty of deterministic models in decision support." Environmental Modelling \& Software 63: $24-31$.

Viscusi, W. K., J. Huber, et al. (2015). "The private rationality of bottled water drinking." Contemporary Economic Policy 33(3): 450-467.

Walski, T. M. and F. L. Parker (1974). "Consumers water quality index." ASCE J Environ Eng Div 100(EE3): 593-611.

Xu, S., T. Wang, et al. (2015). "Dynamic Assessment of Water Quality Based on a Variable Fuzzy Pattern Recognition Model." 12(2): 2230-2248. 
340 Yager, R. R. and L. A. Zadeh (2012). An introduction to fuzzy logic applications in intelligent systems, Springer Science \& Business Media.

342 Yekta, T. S., M. Khazaei, et al. (2015). "Hierarchical distance-based fuzzy approach to evaluate urban water supply systems in a semi-arid region." Journal of Environmental

$344 \quad$ Health Science and Engineering 13(1): 53.

345 Zadeh, L. A. (1965). "Fuzzy sets." Information and Control 8(3): 338-353.

346 Zheng, Y. and F. Han (2016). "Markov Chain Monte Carlo (MCMC) uncertainty analysis for watershed water quality modeling and management." Stochastic Environmental

$348 \quad$ Research and Risk Assessment 30(1): 293-308. 


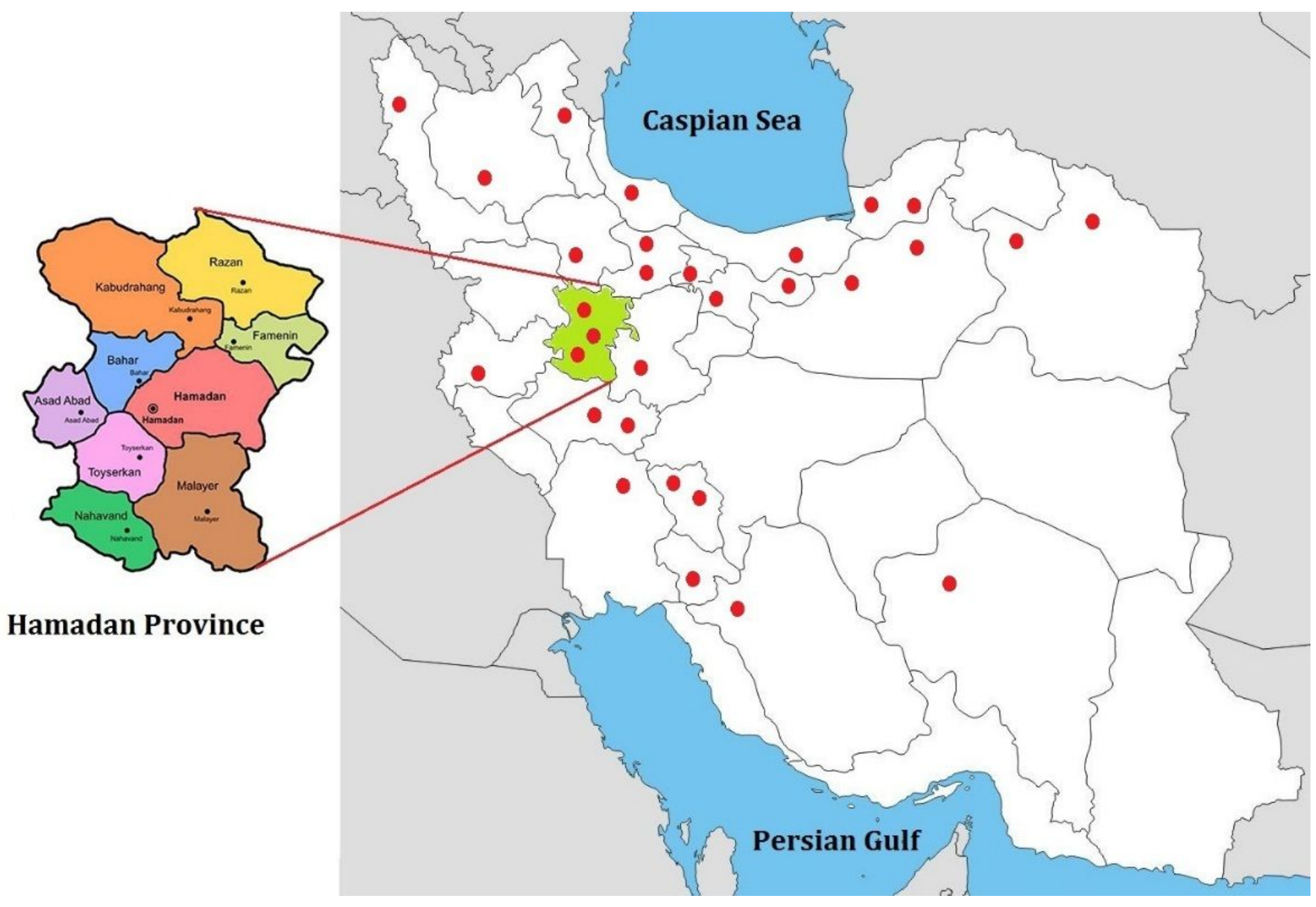

\section{Figure 1}

Map of the study area and the manufactures locations of bottled water samples (Mosaferi, Hajizadeh et al. 2007; Abtahi, Yaghmaeian et al. 2016) Note: The designations employed and the presentation of the material on this map do not imply the expression of any opinion whatsoever on the part of Research Square concerning the legal status of any country, territory, city or area or of its authorities, or concerning the delimitation of its frontiers or boundaries. This map has been provided by the authors. 

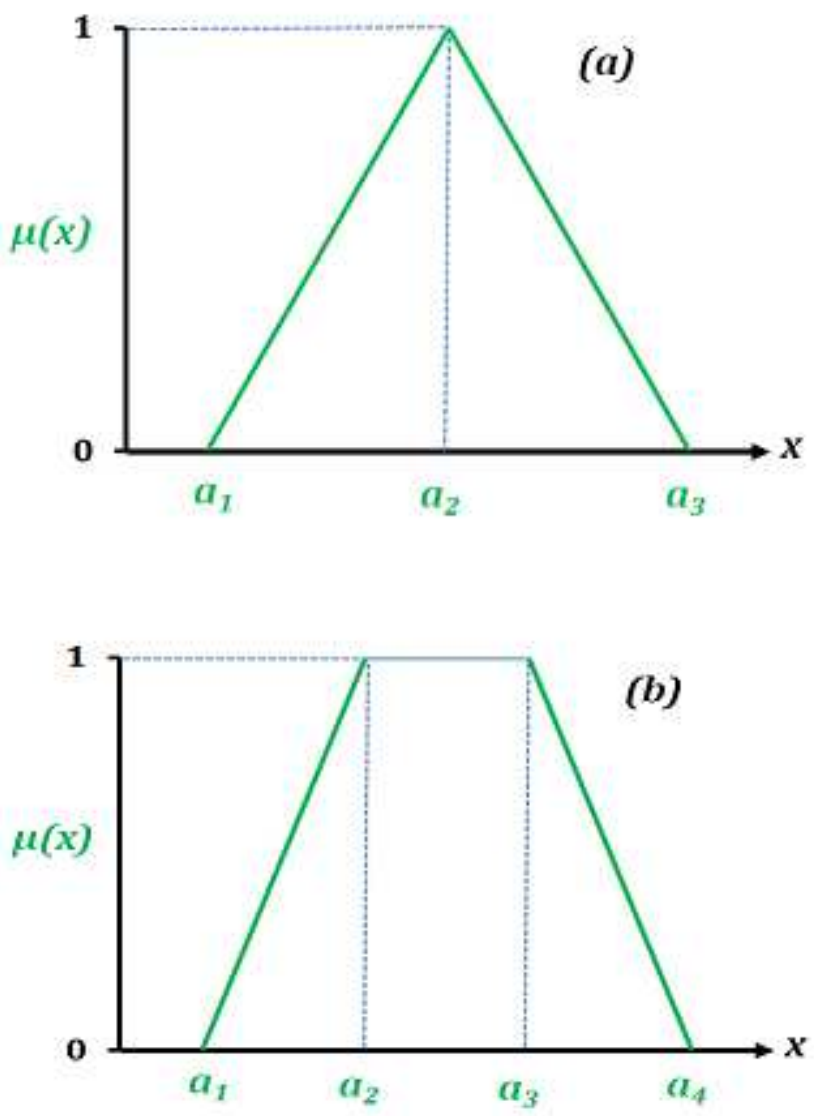

Figure 2

Triangular (a) and trapezoidal (b) fuzzy sets 

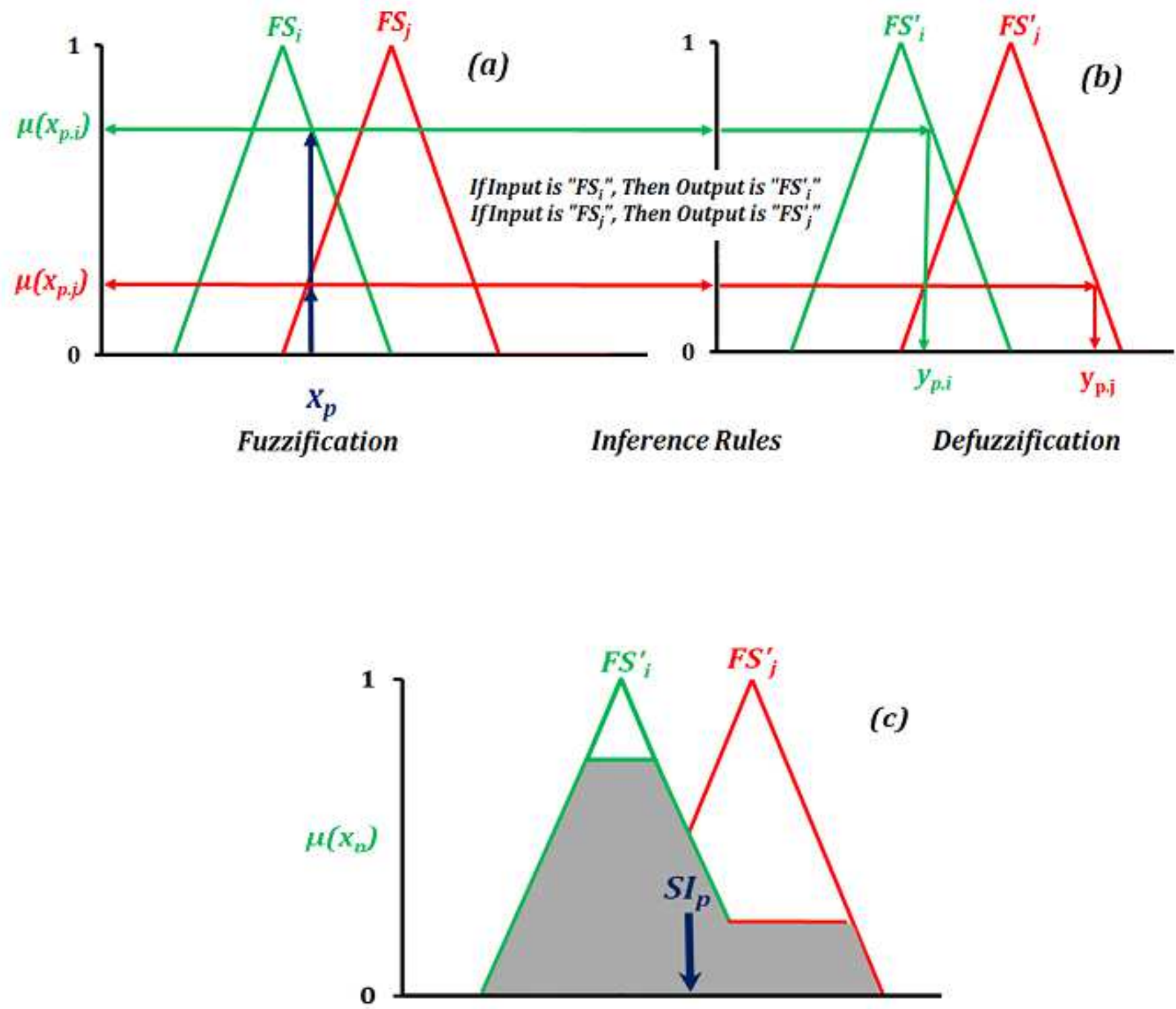

Figure 3

Operation of a single-input-single-output fuzzy inference system (FIS) including the fuzzification (a), using the inference rules (b), and defuzzification by determining the resultant vector, yp,r (c). 


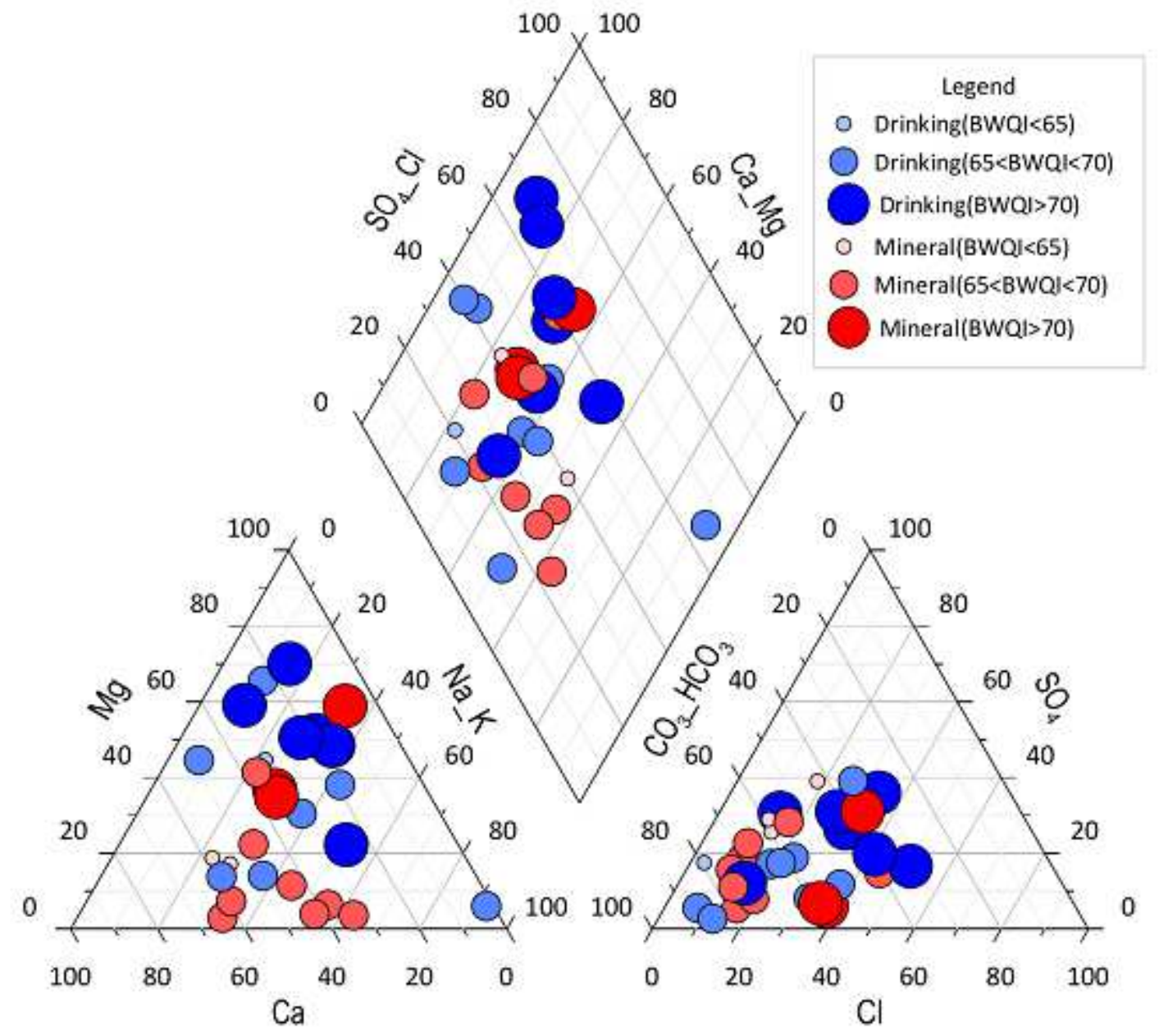

Figure 4

BWQI scores comparison between drinking and mineral bottled water samples. 

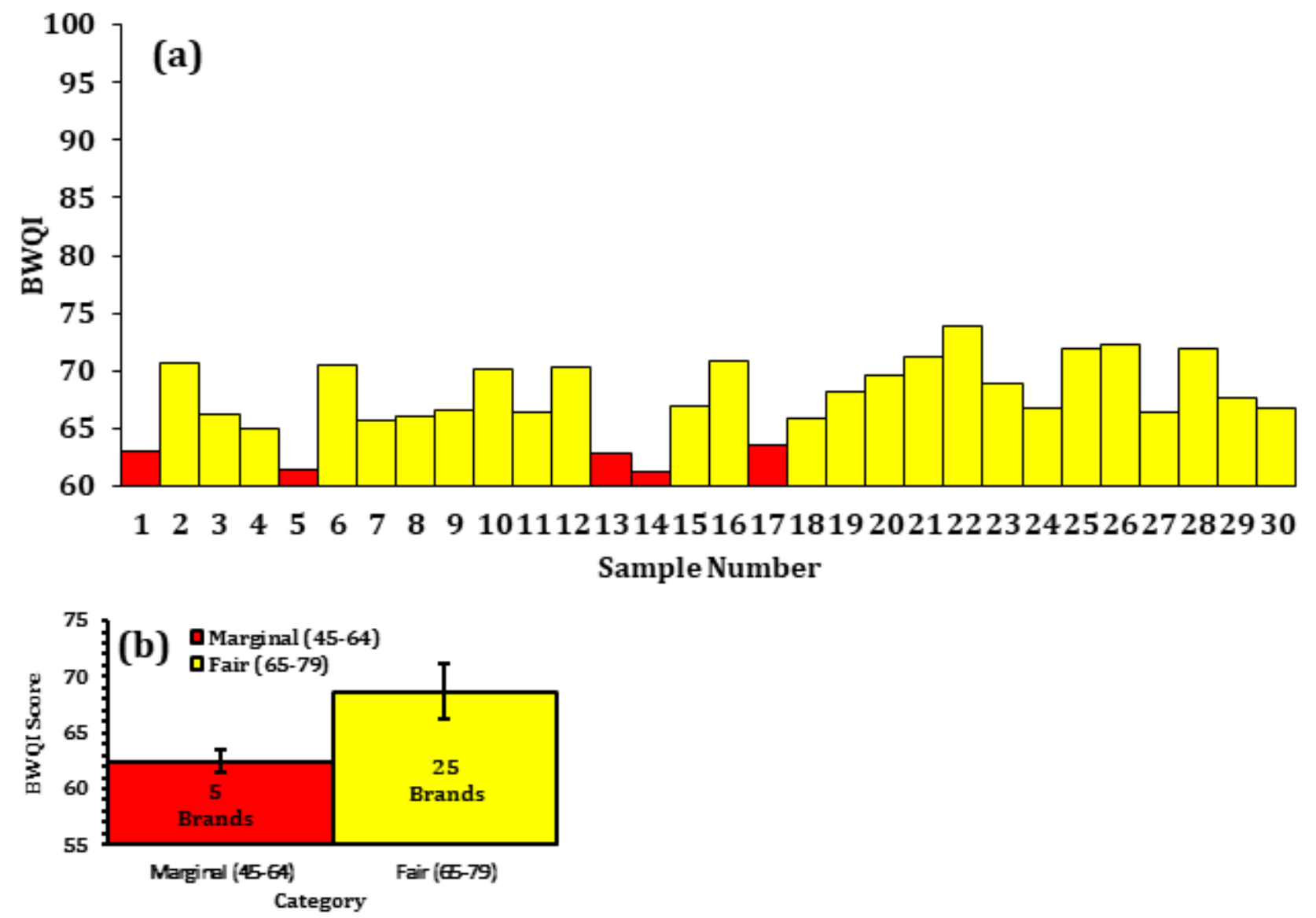

Figure 5

BWQI scores obtained for 30 samples taken from Hamadan province retails (a), the number of brands belonged to the assigned categories (b).

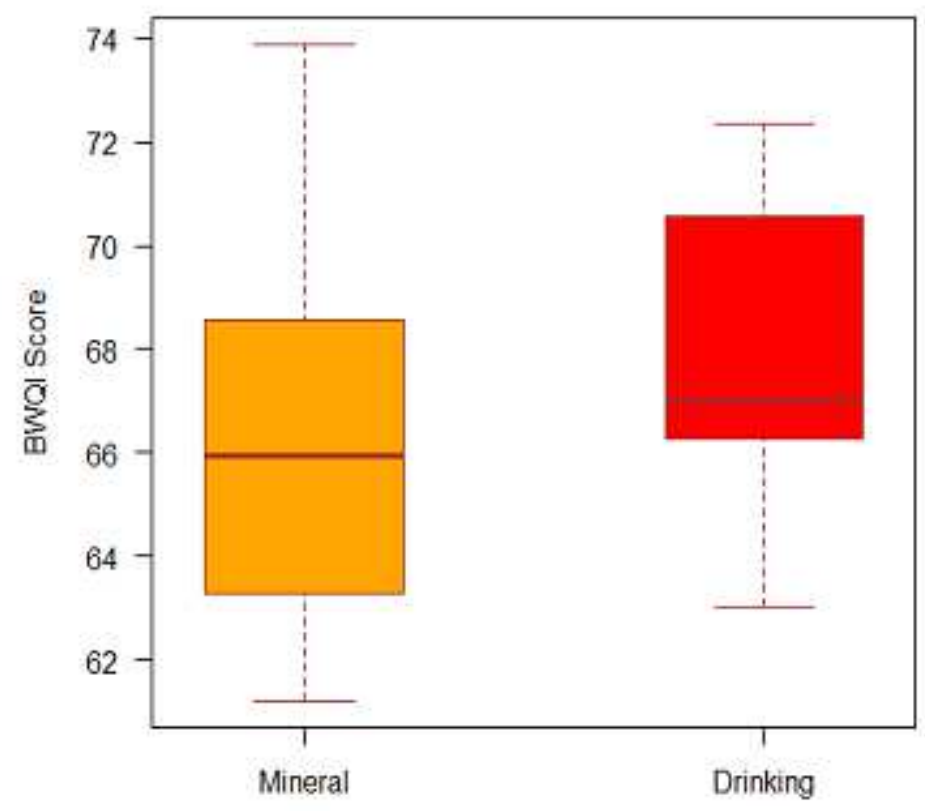

Figure 6 
BWQI scores comparison between drinking and mineral bottled water samples.

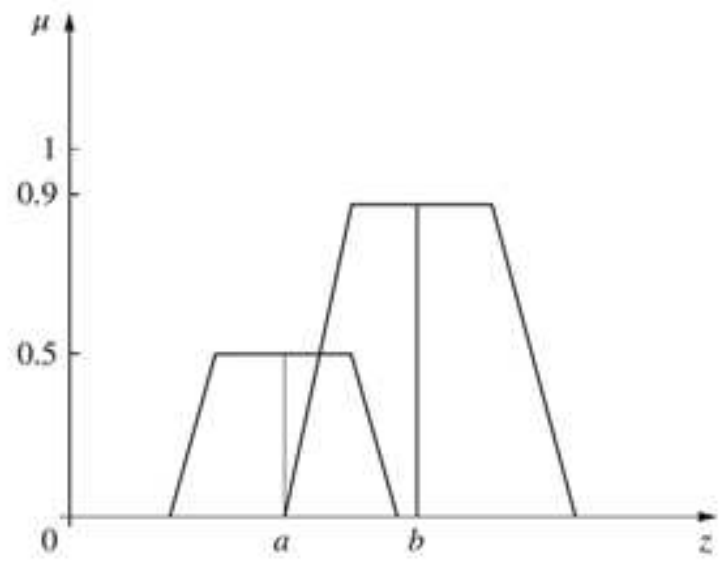

Figure 7

weighted average method of defuzzification (Ross 2004).

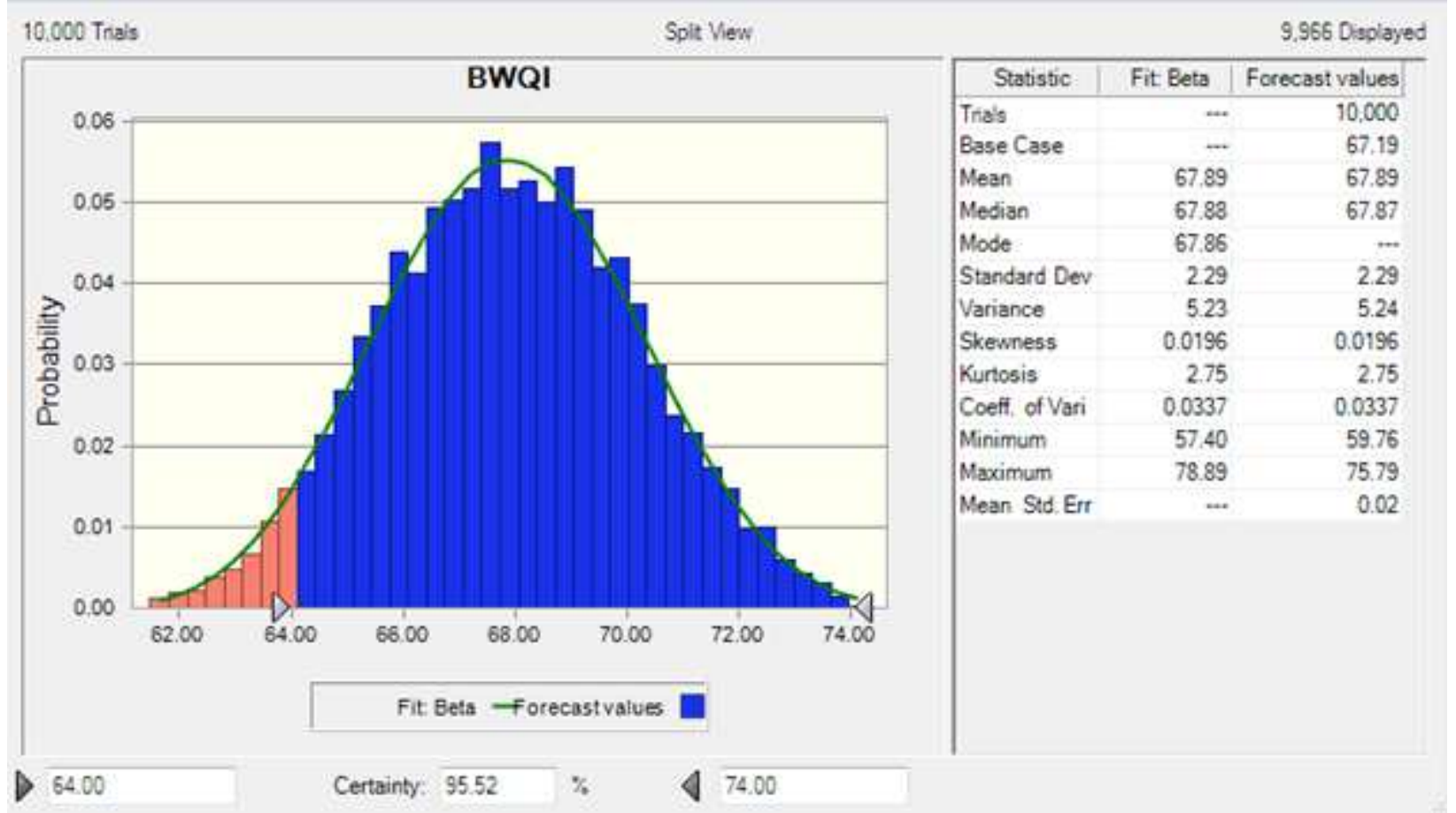

Figure 8

Uncertainty analysis of BWQI scores. 


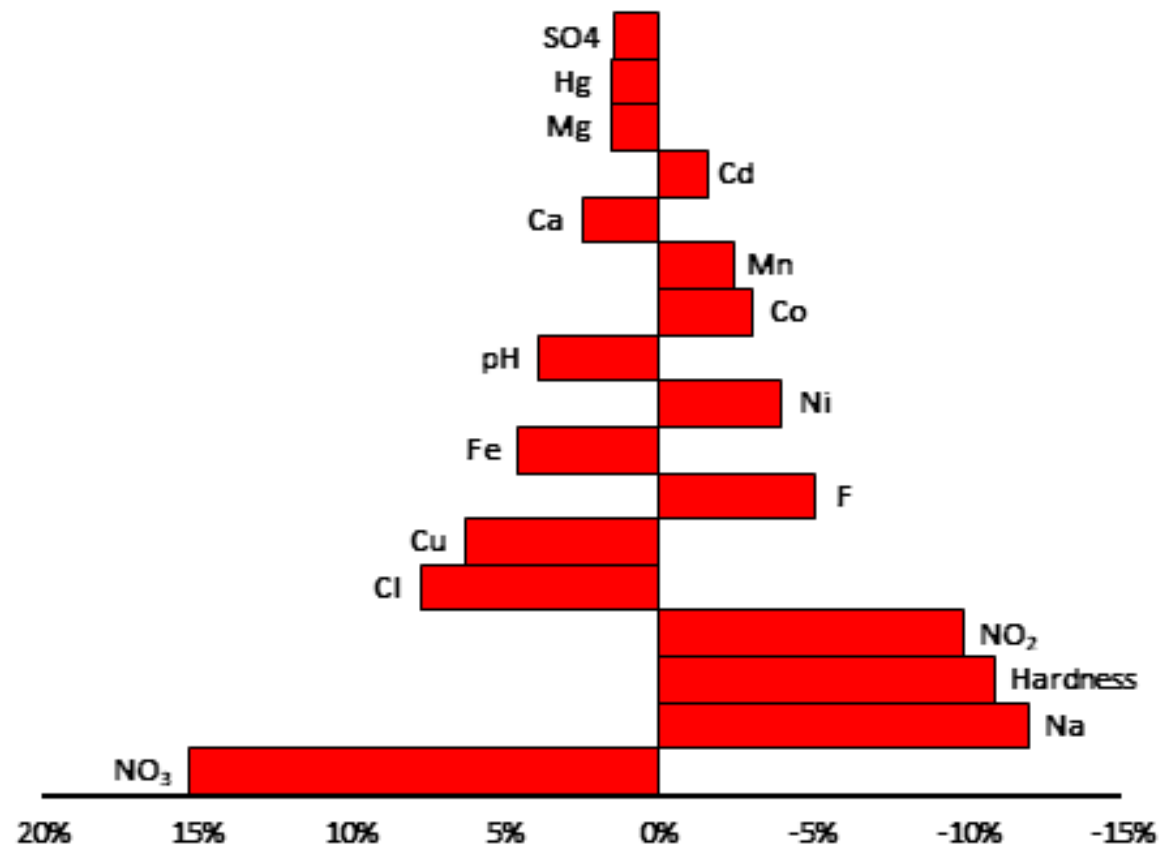

Figure 9

Sensitivity analysis of BWQI parameters. 